\title{
Doğu Akdeniz Bölgesi Tarım İşletmelerinde Oluşan İş Kazaları ve Etkili Faktörler
}

\author{
İsmail GIZZLENCİ ${ }^{1}$, Ali AYBEK$^{2}$ \\ ${ }^{1}$ DSİ 123. Şube Müdürlüğü, İşletme ve Bakım Başmühendisliği, 66100, Yozgat/TÜRKIYE, ${ }^{2}$ Kahramanmaraş Sütçü İmam Üniversitesi, Ziraat \\ Fakültesi, Biyosistem Mühendisliği Bölümü, 46100, Kahramanmaraş/TÜRKIYE \\ ${ }^{1}$ https://orcid.org/0000-0001-9952-2869, ${ }^{2}$ https://orcid.org/0000-0003-3036-8204 \\ $\bowtie$ : aaybek@ksu.edu.tr
}

\section{ÖZET}

Çalışmada Doğu Akdeniz Bölgesi tarım işletmelerinde oluşan iş kazaları ve etkili faktörler belirlenmiş ve değerlendirilmiştir. Bu amaçla bölgeyi oluşturan illerin tarımsal özelliklerini yansıtacak her ilden; merkez ve üç ilçeden toplam 166 işletme sayısı oransal örnekleme yöntemiyle seçilmiştir. Veriler anket aracıllğı ile işletme sahipleri ya da sorumluları ile yüz yüze görüşme yoluyla gerçekleştirilmiştir. Bölgedeki tarım işletmelerinin \%21.1'inde iş kazaları gerçekleşmiştir. Kazalara sırası ile tarım makinaları, tarım traktörleri, elektrik çarpması, hayvanlar ve diğer araçlar neden olmuştur. Kazalar; şarampole uçma (\%42.9), sıkışma-ezilme (\%31.4), vücudu bir parçaya kaptırma (\%14.3), vücuda herhangi bir parçanın çarpması (\%5.7), traktörden düşme (\%2.9) ve traktörün çarpması/başka araçla çarpışma (\%2.9) seklinde gerçekleşmiștir. Tarım makinalarından kaynaklı iş kazaları en fazla pulluk (\%17.1) ve ekim makinası (\%17.1) ile olmuştur. Kazazedelerin \%69.6'sının hafif yaralandığı, \%10.9'unun ağır yaralandığı ve \%4.3'ünün ise kısmen fiziksel engelli olarak görülmüştür. Bölgedeki işletmelerde kazaya karışan traktörlerin \%38.2'si 0-5 yaş, \%41.2'si 6-10 yaş, \%2.9'u 11-15 yaş, $\% 8.8$ ' $\mathrm{i} 16-20$ yaş ve $\% 8.7$ 'si ise $21+$ yaş grubundadır. İşletmecilerin eğitim düzeyleri ile iş kazası oluşma durumu arasında istatistiksel olarak önemli bir ilişki bulunmaktadır $\left(\mathrm{X}^{2}=8.25\right.$; $\mathrm{P}=0.041$ ). Traktör yıllık bakım yapılma durumu ile iş kazası oluşma durumu arasında pozitif bir bağıntı bulunmaktadır $\left(\mathrm{X}^{2}=5.49\right.$; $\mathrm{P}=0.019$ ). Traktör yaşı ile iş kazası oluşma durumu arasında istatistiksel olarak önemli bir ilişki bulunmaktadır $\quad\left(\mathrm{X}^{2}=3.98\right.$; $\mathrm{P}=0.046$ ).
Araştırma Makalesi

\author{
Makale Tarihçesi \\ Geliş Tarihi : 29.09 .2020 \\ Kabul Tarihi : 02.03.2021
}

Anahtar Kelimeler

Tarım işletmeleri

İş kazaları

Doğu Akdeniz Bölgesi

\section{Occupational Accidents Occurring in the Eastern Mediterranean Region and Effective Factors}

\section{ABSTRACT}

In this study, occupational accidents and influential factors in the agricultural enterprises in the Eastern Mediterranean Region were determined and evaluated. For this purpose, total number of 166 enterprises from the central and three districts were selected by proportional sampling method from each province reflecting the agricultural characteristics of the provinces that form the region. The data were carried out by means of face-to-face surveys with enterprise owners or their managers. Occupational accidents occurred as $21.1 \%$ of the agricultural enterprises in the region. The accidents were caused by agricultural machinery, agricultural tractors, electric shock, animals and other vehicles, respectively. The accidents occured in the type of flying to the stockade $(42.9 \%)$, jamming crushing (31.4\%), sucking the body in a part (14.3\%), part hitting on the body (5.7\%) falling from the tractor (2.9\%) and crashing of tractor/crashing with another vehicle (2.9\%). Occupational accidents caused by agricultural machinery were mostly with plow (17.1\%) and sowing machine $(17.1 \%)$ respectively. It was observed that $69.6 \%$ of the casualtys were slightly injured, $10.9 \%$ were seriously injured and $4.3 \%$ were partially physically disabled, respectively. And also, $38.2 \%$ of the

\section{Research Article}

$\begin{array}{ll}\text { Article History } & \\ \text { Received } & : 29.09 .2020 \\ \text { Accepted } & : 02.03 .2021\end{array}$

Keywords

Agricultural enterprises

Occupational accidents

Eastern Mediterranean Region 
tractors involved in the accident in the region were $0-5$ years old, $41.2 \%$ were 6 - 10 years old, $2.9 \%$ were $11-15$ years old, $8.8 \%$ were 16 20 years old and $8.7 \%$ were $21+$ age group. There is a statistically significant relationship between the education level of the operators and the occurrence of occupational accidents $\left(\mathrm{X}^{2}=8.25 ; \mathrm{P}=0.041\right)$. There is a positive correlation between the annual maintenance of the tractor and the occurrence of occupational accidents $\left(\mathrm{X}^{2}=5.49\right.$; $\mathrm{P}=0.019$ ). There is a statistically significant relationship between the age of tractors and the occurrence of occupational accidents $\left(\mathrm{X}^{2}=3.98\right.$; $\mathrm{P}=0.046$ ).

\begin{tabular}{ll}
\hline Atıf İ̧̧in: & Gizlenci İ, Aybek A. 2021. Doğu Akdeniz Bölgesi Tarım İşletmelerinde Oluşan İş Kazaları ve Etkili Faktörler. \\
To Cite: & KSÜ Tarım ve Doğa Derg 24 (5): 1068-1083. DOI: 10.18016/ksutarimdoga.vi.801602. \\
& Gizlenci İ, Aybek A. 2021. Occupational Accidents Occurring in the Eastern Mediterranean Region and \\
& Effective Factors. KSU J. Agric Nat 24 (5): 1068-1083. DOI: 10.18016/ksutarimdoga.vi.801602.
\end{tabular}

\section{GIRISS}

Tarım sektörü; gıdaların üretimi ve beslenme ile doğrudan ilgisi, aktif nüfus ve işgücündeki oranı, milli gelire katkısı ve sanayi sektörüne sağladığı hammadde ve sermaye yanında, sağlıklı çevrenin oluşması ve korunması, ekolojik dengenin kurulması ve sürdürülebilirliği açısından da tüm ülkeleri ilgilendirmekte ve bu nedenle ekonomik ve sosyal bir sektör olma özelliğini korumaktadır. Hem ekonomi hem de istihdam açısından bakıldığında tarım sektöründe iş sağllğ̆ ve güvenliğinin ihmal edilemeyecek kadar önemli bir konu olduğu görülmektedir.

Endüstriyel sektörler içerisinde tarım gerek dünyada gerekse Türkiye'de istihdamda önemli bir yer oluşturmaktadır. Ekonomik ve teknolojik gelişmeler ile sektörün dinamik yapısı tarım çalışanlarının iş ve çalışma koşullarını, buna bağlı olarak çalışma hayatı ve yaşam standartlarını etkilemektedir. Tarım sektörü, inşaat ve madencilikle beraber dünyadaki en tehlikeli iş kollarından biridir. Uluslararası Çalışma Örgütü'ne (ILO) göre, 1.3 milyar tarım işçisinden her yıl 170000 kişi ölmekte önemli bir kısmı ciddi şekilde yaralanmakta veya meslek hastalığına yakalanmaktadır (Yavuz ve Şimşek, 2012). Böcek ilaçları, diğer kimyasallara maruz kalma ile tarım makineleri kazaları sektördeki ölüm, yaralanma ve hastalıkların iki temel nedenidir.

Tarım sektörü, Cumhuriyetin kuruluşundan bugüne kadar, ülkenin ekonomik ve sosyal gelişiminde çok önemli bir görevi üstlenmiş ve bu görevi bugüne kadar etkin bir şekilde sürdürmüş ve sürdürmeye de devam edecektir. 1960'tan sonra ekonomik gelişmede önceliğin sanayi sektörüne kaydırılması ve diğer sektörlerin buna paralel olarak gelişmesi tarım sektörünün ekonomi içindeki payını azaltmış ve bu gelişme yapısal bir dönüşüm olarak kabul edilmiştir. Fakat tarım sektörü bu gelişmelere rağmen, ülke nüfusunun büyük bir çoğunluğuna gelir ve istihdam sağlamayı halen sürdürmektedir. Nitekim kırsal alanda yaşayan insanların en başta gelen istihdam kaynağı yine tarımdır (Yücel, 2012).
Tarımsal Mekanizasyon; insanları ve biyolojik malzemeleri göz önünde tutarak bitkisel ve hayvansal üretimde kullanılan alet, makine, sistem ve teknolojilerin, mekanik, elektronik ve ergonomik ilkelere göre en uygun tasarımlarını ve üretimlerini gerçekleştiren, bu unsurların en uygun kullanımını sağlayan ve enerji gereksinimlerini saptayan, yenilenebilir enerji kaynaklarının tarımda kullanım olanaklarını geliştiren çok disiplinli bir bilim dalıdır.

Teknolojideki yeniliklere paralel olarak traktörlerde motor gücü ve performansında hızlı bir gelişme gözlenmiş, bugün kullanılan traktörler, teknolojik olarak son şeklini almıştır. Traktörler; bir taraftan teknolojik olarak gelişirken, sürücünün rahat çalışmasını sağlamak ve güvenlik açısından karşılaşabileceği riskleri en aza indirmek amacıyla başta kabin, ergonomik tasarım olmak üzere pek çok yenilik hayata geçirilmiştir. Özellikle güvenlik konusunda sıkı kurallar ortaya konmuş ve çeşitli yönetmeliklerle de bunlar denetim altına alınmıştır (Anonim, 1999).

Türkiye'de tarımın sürdürülebilirliği; tarım çalışanlarının, çalışma yerlerindeki sağlık ve güvenliklerinin temini ile mümkün olabilecektir. Türkiye'de tarım makineleri kazaları ile ilgili kayıt bulmak oldukça güçtür. İlgili sektörde, çalışanların çoğu kendi nam ve hesabına çalışanlar olduğundan, adli vaka dışında kaza/meslek hastalığı kayıtlarını tutmaya yönelik bir sistem mevcut değildir.

Dünya'da yapılan araştırmalarda tarım sektöründe iş sağlığı ve güvenliği açısından pek çok farklı risklerin (tarım makineleri, pestisitler, gaz ve tozlar, hayvanlar, vb.) söz konusu olduğu bildirilmektedir.

Türkiye'de tarımda iş kazalarına yönelik bazı çalışmalar (Doğan, 1992; Peker ve Özkan, 1994; Gölbaşı, 2002; Öz, 2005; Bülbül, 2006; Akbolat ve ark., 2007; Perktaş, 2007; Öztürk, 2008; Ünal ve ark., 2008; Yücel, 2012; Erbörü, 2014; Yıldırım ve Altuntaş, 2015; Baydaş ve Altuntaş 2017; Sağlam ve ark., 2017; Alçayır, 2018; Özkan ve Dilay, 2020) yapılmıştır. Teknolojik gelişmelere bağlı olarak kullanılan traktör, tarım alet ve makinalarının kullanımına ve iş 
güvenliğine yönelik alınacak önlemler son yıllarda önem kazandığı için yeni istatistiksel bilgi ve verilere ulaşma zorunluluğunu ortaya çıkarmaktadır. $\mathrm{Bu}$ anlamda Türkiye'de konuya ilişkin çalışmalar henüz başlangıç düzeyindedir. Bu nedenle sektörün mevcut durumunun analizi ve gerekli çözüm önerilerinin oluşturulması için alana ilişkin araştırmaların ülke çapında yoğunlaştırılması, elde edilen verilerin işlenmesi ve yönetim birimleri ve üreticilerce sistematik şekilde kullanılması gerekmektedir.

Türkiye'de genel olarak tarımsal üretim; bitkisel ve hayvansal üretimin organik bir bütün olarak gerçekleştirildiği tarım işletmeleri tarafından yapılmaktadır. Doğu Akdeniz Bölgesi, bitkisel ve hayvansal üretim açısından Türkiye'nin önemli bir yöresidir. Sektöre ilişkin yöresel bazda kapsamlı olarak yapılacak araştırmalar, sağlıklı ve güvenli bir üretim planlaması ve ekonomik işletmecilik politikalarına temel teşkil edecektir.

Bu çalışmada, Doğu Akdeniz Bölgesi (Adana, Hatay, Kahramanmaraş, Osmaniye) tarım işletmelerinde oluşan iş kazaları ve etkili faktörler belirlenmiş ve değerlendirilmiştir

Çizelge 1. Anket uygulanan bölge bilgileri

Table 1. Area information surveyed

\begin{tabular}{|c|c|c|c|c|}
\hline İller (Provinces) & $\begin{array}{c}\text { İlçeler } \\
\text { (Districts) }\end{array}$ & $\begin{array}{l}\text { Toplam tarım işletmesi sayıs } \\
\text { (Adet) } \\
\text { (Total number of agricultural } \\
\text { enterprises) (Number) }\end{array}$ & $\begin{array}{c}\text { Oranlar }(\%) \\
\text { (Proportions) }\end{array}$ & $\begin{array}{c}\text { Anket uygulanan tarım } \\
\text { isletmesi sayısı (Adet) } \\
\text { (Number of agricultural } \\
\text { enterprises surveyed) (Number) }\end{array}$ \\
\hline \multirow{3}{*}{ Adana } & Seyhan & 1816 & 5.8 & 10 \\
\hline & Ceyhan & 5847 & 18.8 & 31 \\
\hline & Karataş & 2148 & 6.9 & 11 \\
\hline \multirow{3}{*}{ Hatay } & Dörtyol & 1210 & 3.9 & 7 \\
\hline & Kirıkhan & 3586 & 11.5 & 19 \\
\hline & Kumlu & 1017 & 3.3 & 6 \\
\hline \multirow{3}{*}{ Kahramanmaraş } & Göksun & 2594 & 8.3 & 14 \\
\hline & Pazarcık & 4869 & 15.6 & 26 \\
\hline & Türkoğlu & 1889 & 6.1 & 10 \\
\hline \multirow{3}{*}{ Osmaniye } & Toprakkale & 408 & 1.3 & 2 \\
\hline & Kadirli & 4022 & 12.9 & 21 \\
\hline & Düziçi & 1751 & 5.6 & 9 \\
\hline \multicolumn{2}{|l|}{ Toplam (TotaI) } & 31157 & 100 & 166 \\
\hline
\end{tabular}

\section{Yöntem}

\section{Örnek hacminin belirlenmesi}

Araştırma kapsamında ele alınan illerin ilçelerindeki tarım işletmesi sayıları, Tarım ve Orman Bakanlığı, İl Tarım ve Hayvancılık Müdürlüğü, Çiftçi Kayıt Sistemi verilerinden alınmıştır. Anket yapılacak işletme sayısı oransal örnek hacmi formülü ile belirlenmiştir (Newbold, 1995). Sonlu bir popülasyon için belli bir özelliği taşıyanların bilinen veya tahmin edilen oranına göre örnek hacmi Eşitlik 1'deki gibidir. p değeri daha önceki araştırmalardan elde edilebileceği gibi sezgisel olarak da tahmin edilebilir. Maksimum

\section{MATERYAL ve METOD}

\section{Materyal}

Araştırmanın materyalini, Doğu Akdeniz Bölgesi'nde (Adana, Hatay, Kahramanmaraş, Osmaniye) oransal örnekleme yöntemi ile belirlenen toplam 166 tarım işletmesinden elde edilen anket verileri oluşturmaktadır. İşletmelerin belirlenmesinde her bir ilde tarım teknolojilerinin yoğun olarak kullanıldığı ilk üç ilçe seçilmiştir (Çizelge 1). Anket verileri, 2018 yılı Ocak-Nisan döneminde, yüz yüze görüşme yapılarak elde edilmiştir. Anket soruları yazarlar tarafindan geniş bir literatür taraması neticesinde hazırlanmış olup, daha sonra konu uzmanları ile yapılan görüşmeler ile son şeklini almıştır. Anket formunda sorulara ilişkin dört genel başlık yer almıştır. Bunlar; 1) Tarım işletmecileri ve çalışanların özellikleri, 2) Tarım işletmelerinin genel özellikleri, 3) Tarım işletmelerinde kullanılan mekanizasyon araçlarına ilişkin bilgiler, 4) Tarım işletmelerinde oluşan iş kazaları ve etkili faktörlere ilişkin bilgilerdir. Sorular, kapalı uçlu, açık uçlu ve Likert ölçeğinde hazırlanmıştır. örnek hacmine ulaşmak için $\mathrm{p}=0.5$ alınmıştır. p'nin 0.5 'den daha az veya daha yüksek değerleri örnek hacmini düşürür. $\mathrm{O}$ nedenle p'nin bilinmediği durumlarda maksimum örnek hacmiyle çalışmak olası hatayı azaltacağından p=0.5 alınmalıdır (Miran 2015).

$n=\frac{N * p *(1-p)}{(N-1) * \sigma_{P}^{2}+p *(1-p)}$

Burada;

n : Örnek hacmi,

N : Popülasyondaki işletme sayısı, 
$\sigma_{\mathrm{p}}^{2} \quad$ : Oranin varyansı,

$\mathrm{r} \quad$ : Ortalamadan sapma (\%1),

$\mathrm{Z}_{\alpha / 2} \quad$ : Z cetvel değeri (2.58),

$\mathrm{p} \quad$ : İşletme sayısının popülasyondaki oranını göstermektedir.

Oranın varyansına (Eşitlik 2) bağlı olarak \%99 güven aralığında $(Z=2.58)$ ve ortalamadan \% 0.1 sapma ile anket yapılacak işletme sayısı 166 olarak belirlenmiştir (Eşitlik 3).

$$
\begin{aligned}
& \sigma_{\mathrm{p}}^{2}=\left(\frac{\mathrm{r}}{\mathrm{z}_{\alpha / 2}}\right)^{2}=\left(\frac{0.10}{2.58}\right)=0.001502 \\
& n=\frac{31157 * 0.5 *(1-0.5)}{(31157-1) * 0.001502+0.5 *(1-0.5)}=166
\end{aligned}
$$

\section{Verilerin değerlendirilmesi}

İki değişken arasında ilişki olup olmadığını belirlemek veya iki değişken arasındaki ilişkinin istatistiksel olarak anlamlı olup olmadığını belirlemek amacıyla Ki-Kare (X²) bağımsızlık testi kullanılır (Nakip, 2006; Baş, 2008; Tekin, 2009).

Anket formu ile elde edilen bilgilerin gerekli kodlamaları yapılarak, veriler bilgisayarda SPSS programı yardımı ile değerlendirilmiştir. Verilerin tanımlayıcı istatistik değerleri tablolara aktarılarak yorumlanmıştır. İşletme, işletmeci özellikleri ve anket kapsamındaki özellikler ile işletmede meydana gelen iş kazası oluşma durumu arasındaki ilişkileri incelemek amacıyla $\mathrm{X}^{2}$ bağımsızlık testinden yararlanılmıştır. Testin geçerli olabilmesi için sorulara alınan yanıtlar daraltılmıştır.

\section{BULGULAR ve TARTIŞMA}

\section{Tarım İşletmecileri ve Çalışanların Özellikleri}

Anket kapsamındaki işletme sahiplerinin; \% 98.8'i erkek ve \% 1.2'si kadın olup yaş dağılımları açısından en yüksek (\%34.9) oran, 36-45 yaş grubudur, bunu sırası ile 46-55 yaş grubu (\%32.5), $56+$ yaş grubu (\%16.9), 26-35 yaş grubu (\%13.9) ve 15-25 yaş grubu (\%1.8) izlemektedir. İşletme sahiplerinin eğitim durumu değerlendirildiğinde, bölge genelinde \% 59'u ilkokul, \% 22.9'u ortaokul, \%11.4'ü lise ve \%6.6'sı üniversite mezunudur. İşletme sahiplerinin tarımdaki iş deneyimlerine bakıldığında, yarısı (\%50) 25 yıldan daha fazla deneyimlidir. İş deneyimi 16-20 yıl olanların oranı $\% 25.3,11-15$ yıl olanların oranı $\% 12.1$ ve 6-10 yıl olanların oranı ise \%10.2'dir. Şenel (2006), söz konusu bölgede yapmış olduğu bir çalışmada, işletme sahiplerinin eğitim düzeyini, okur-yazar olmayanları \%3.4, ilkokul \%50.7, ortaokul \%22.9, lise $\% 21.5$ ve üniversite mezunu olanları \%1.5 olarak belirlemiştir. Bu veriler karşılaştırıldığında geçen 10 yıldan fazla bir süreçte tarım işletmecilerinin eğitim düzeyinde bir değişimin olmadığı ve düşük olduğu ayrıca genel anlamda işletme sahiplerinin tarımda deneyimli olduğu söylenebilir.

Anket uygulanan tarım işletmelerinin \%62.7'sinde hiç çalışan bulunmamaktadır. İşletmelerin \%18.7'sinde 1 çalışan, \%10.2'sinde 2 çalışan, \%4.8'inde 3 çalışan, $\% 1.8$ 'inde 4 çalışan, \%0.6'sında 5 çalışan ve \%1.2'sinde ise 6 çalışan bulunmaktadır. İşletmeciler ile yapılan görüşmelerde işletmelerde daimi çalışan bulundurulmadığı, dönemsel olarak mevsimlik işçi çalıştırıldığ $\breve{g}_{1}$ bildirilmiştir.

\section{Tarım İşletmelerinin Genel Özellikleri}

Yapılan anket sonucu değerlendirmelerine göre bölgedeki tarım işletmelerinin \%24.7'si 5 ha'dan küçük, \%34.3'ü 5.1-10 ha, \%19.3'ü 10.1-15 ha, \%10.8'i 15.1-20 ha ve \%10.8'i 20 ha'dan daha büyük işletme büyüklüğüne sahiptir. Bölgede sulu arazisi bulunan tarım işletmelerinin \%47.6'sı ve kuru arazi varlığı olan işletmelerin \%78.9'u $0-5$ ha işletme büyüklüğüne sahiptir. İşletmelerin \%76.5'i bitkisel üretim, \%1.2'si hayvansal üretim ve \%22.3'ü bitkisel+hayvansal üretim faaliyeti gerçekleştirmektedir.

Tarım İşletmelerinde Kullanılan Mekanizasyon Araçlarına İlişkin Bilgiler

Ele alınan bölgedeki tarım işletmelerinin \%0.6'sında hiç traktör olmadığı, \%87.3'ünde bir traktör, $\% 10.2$ 'sinde iki traktör ve \%1.8'inde üç traktör olduğu belirlenmiştir. Şenel (2006), bölgede yapmış olduğu araştırmasında işletmelerin \%89.3'ünde bir traktör, \%7.8'inde iki traktör, \%0.5'inde üç traktör, \%2.4'ünde dört traktör olduğunu belirlemiştir. Aybek ve Hurşitoğlu (2002), Kahramanmaraş yöresinde tarım işletmelerinin mekanizasyon özelliklerini belirlemek amacıyla yapmış oldukları çalışmada işletmelerin \%88'inde bir traktör, \%11'inde iki traktör, \%1'inde üç traktör olduğunu belirlemişlerdir. Geçen süreye rağmen bölgedeki işletmelerin traktör sayılarında artış olmadığ 1 görülmektedir. Bu duruma yaşanan ekonomik krizler ve işletmeler için devlet desteklemelerinin yetersiz kalmasının etkili olduğu söylenebilir.

Anket kapsamındaki işletmelerin \%34.9'unun 0-5 yaş grubu, \%28.3'ünün 6-10 yaş grubu, \%10.2'sinin 11-15 yaş grubu, \%4.2'si 16-20 yaş grubu ve \%22.3'ünün $21+$ yaş grubu traktörlere sahip olduğu belirlenmiştir. Yılmaz (2018), Türkiye'de traktör yıllık kullanımının ortalama 500 saat/yıl olduğunu, buna göre traktör ekonomik ömrünü 20 yıl olarak tamamladığını bildirmiştir. Buna göre bölgede kullanılan tarım traktörlerinin yaklaşık \%25'inin ekonomik ömrünü tamamladığı, \%15’inin de yakın dönemde tamamlayacağı görülmektedir.

Araştırma kapsamındaki tarım işletmelerinde kullanılan traktör markalarına bakıldığında, en yüksek (\%24.7) Massey Ferguson gelmektedir. Bunu 
New Holland (\%19.3), Fiat (\%15.1), Tümosan (\%11.4) ve Case (\%11.4), Erkunt (\%8.4), John Deere (\%7.2) ve Hattat (\%5.4) izlemektedir. Yıl içerisinde traktör bakım ve kontrollerini yapan işletme oranı \%76.5, yapmayanların oranı ise \%23.5 olarak belirlenmiştir.

Bölgedeki tarım işletmelerinin tarım makinalarına sahip olma durumu incelendiğinde; toprak işleme makinaları \%55, ekim makinaları \%35, ilaçlama makinaları \%72.9, gübreleme makinaları \%23.2, römork \%92.2 olarak belirlenmiştir.

Tarım İşletmelerinde Oluşan İş Kazaları ve Etkili Faktörlere İlişkin Bilgiler

Anket kapsamındaki tarım işletmelerinde, oluşan iş kazası oranları Çizelge 2'de, iş kazalarına neden olan başlıca faktörler ise Çizelge 3’te verilmiştir.

Çizelge 2. Tarım işletmelerinde oluşan iş kazası oranları

Table 2. Occupational accident rates in agricultural enterprises

\begin{tabular}{|c|c|c|c|c|c|c|c|c|c|c|}
\hline \multirow{3}{*}{$\begin{array}{l}\text { İş kazası } \\
\text { oluştu mu? } \\
\text { (Did occupational } \\
\text { accident occur?) }\end{array}$} & \multicolumn{8}{|c|}{ İller (Provinces) } & \multirow{2}{*}{\multicolumn{2}{|c|}{$\begin{array}{c}\text { Doğu Akdeniz Bölgesi } \\
\text { (Eastern Mediterranean } \\
\text { Region) }\end{array}$}} \\
\hline & \multicolumn{2}{|c|}{ Adana } & \multicolumn{2}{|c|}{ Hatay } & \multicolumn{2}{|c|}{ Kahramanmaraş } & \multicolumn{2}{|l|}{ Osmaniye } & & \\
\hline & \begin{tabular}{|c|} 
İşletme \\
Sayısı \\
(Enterprise \\
Number) \\
\end{tabular} & $\%$ & \begin{tabular}{|c|} 
İşletme \\
Sayısı \\
(Enterprise \\
Number $)$ \\
\end{tabular} & $\%$ & \begin{tabular}{|c|} 
İşletme \\
Sayısı \\
(Enterprise \\
Number $)$ \\
\end{tabular} & $\%$ & \begin{tabular}{|c|}
$\dot{\mathrm{I}}_{\text {şletme }}$ \\
Sayısı \\
(Enterprise \\
Number $)$ \\
\end{tabular} & $\%$ & $\begin{array}{l}\text { İşletme } \\
\text { Sayısı (Enterprise } \\
\text { Number) }\end{array}$ & $\%$ \\
\hline Evet $(Y e s)$ & 10 & 19.2 & 4 & 12.5 & 13 & 26 & 8 & 25 & 35 & 21.1 \\
\hline Hayır $(\mathrm{No})$ & 42 & 80.8 & 28 & 87.5 & 37 & 74 & 24 & 75 & 131 & 78.9 \\
\hline Toplam (TotaI) & 52 & 100 & 32 & 100 & 50 & 100 & 32 & 100 & 166 & 100 \\
\hline
\end{tabular}

Çizelge 3. Tarım işletmelerinde iş kazalarına neden olan başlıca faktörler

Table 3. Main factors causing occupational accidents in agricultural enterprises

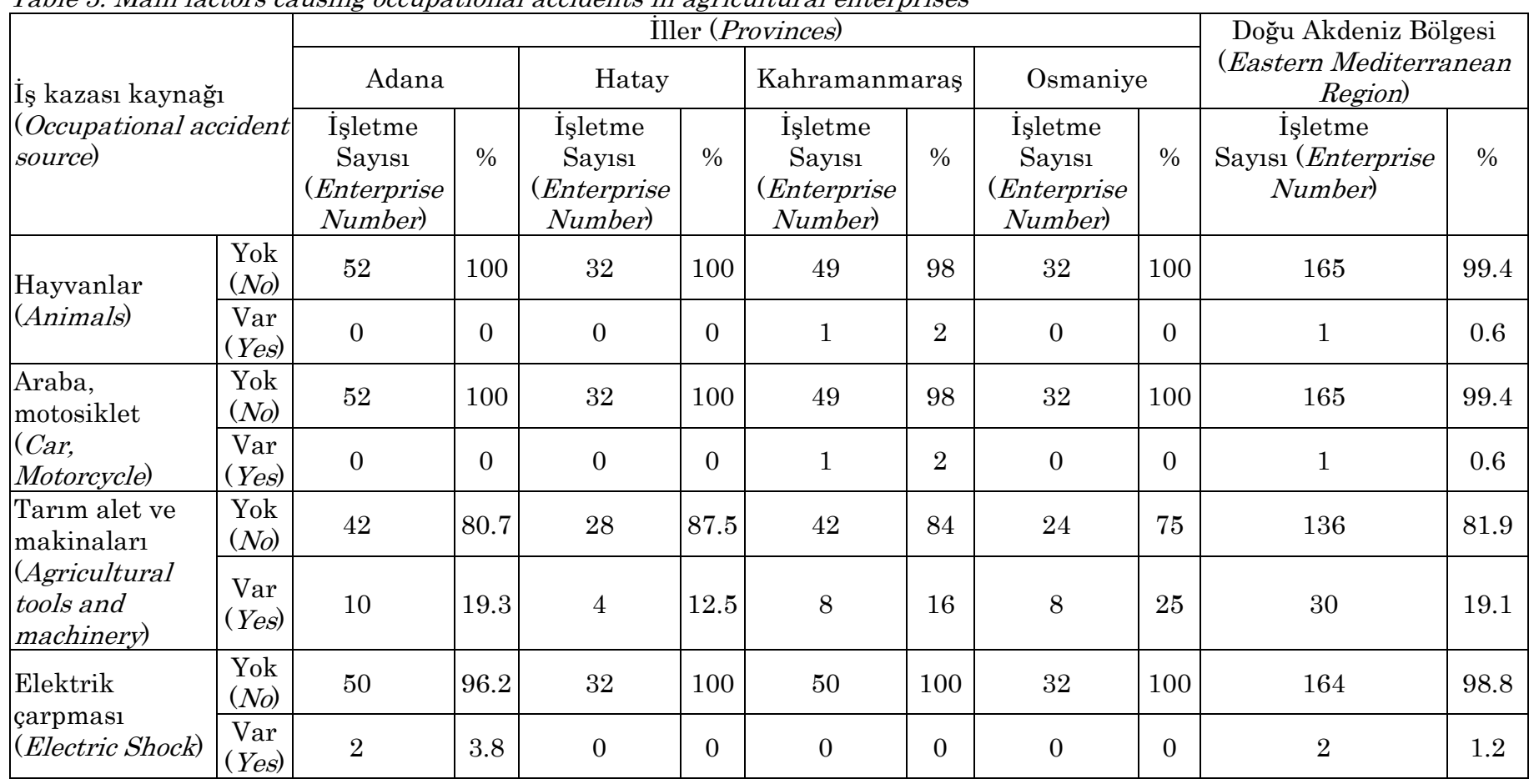

Bölgedeki tarım işletmecilerinin \%21.1'i iş kazası geçirdiklerini bildirmişlerdir. Bölgede iş kazaları en fazla Kahramanmaraş ilinde (\%26), en az ise Hatay ilinde (\%12.5) meydana gelmiştir (Çizelge 2). İş kazası geçiren işletmelerde en fazla tarım alet ve makinaları kazalara neden olmaktadır. Bunu sırası ile elektrik çarpması, hayvanlar ve araç kazaları izlemektedir (Çizelge 3). Aybek ve Sabancı (2001), diğer ülkelerde yapılan tarımsal çalışmalarda başlıca kaza faktörlerini tarım makinaları (\%18), tarım traktörleri (\%8), hayvanlar (\%17), el aletleri (\%8) güç makinaları (\%5) ve diğer makinalar (\%14) olarak bildirmişlerdir.
Bu çalışmada elde edilen değerler, kaza faktörleri açısından hayvan faktörü hariç benzerlik göstermektedir.

İşletmelerde iş kazalarının oluştuğu yerler Çizelge 4'te ve iş kazalarının gün içinde oluştuğu zamanlar Çizelge 5 'te, traktör ve tarım makineleri ile yapılan iş kazalarının oluş şekli Çizelge 6'da verilmiştir.

Bölgedeki işletmelerde meydana gelen iş kazalarının oluştuğu yerler açısından değerlendirildiğinde, kazaların \%42.9'u işletme içinde, \%11.4'ü köy yolunda, $\% 14.3$ 'ü tarla yolunda, \%28.6'sı tarlada, \%2.9'u da şehir yolunda oluşmuştur (Çizelge 4). 
Çizelge 4. Tarım işletmelerinde iş kazalarının oluştuğu yerler

Table 4. Places where occupational accidents occur in agricultural enterprises

\begin{tabular}{|c|c|c|c|c|c|c|c|c|c|c|}
\hline \multirow{3}{*}{\begin{tabular}{|l}
$\mathrm{I}_{\text {Ş kazasinın oluştuğu }}$ \\
yer \\
(Place of Occupational \\
Accident $)$
\end{tabular}} & \multicolumn{8}{|c|}{ İller (Provinces) } & \multirow{2}{*}{\multicolumn{2}{|c|}{$\begin{array}{c}\text { Doğu Akdeniz Bölgesi } \\
\text { (Eastern Mediterranean } \\
\text { Region) }\end{array}$}} \\
\hline & \multicolumn{2}{|l|}{ Adana } & \multicolumn{2}{|l|}{ Hatay } & \multicolumn{2}{|c|}{ Kahramanmaraş } & \multicolumn{2}{|c|}{ Osmaniye } & & \\
\hline & $\begin{array}{c}\text { İşletme } \\
\text { Sayısı } \\
\text { (Enterprise } \\
\text { Number) }\end{array}$ & $\%$ & $\begin{array}{c}\text { İşletme } \\
\text { Sayısı } \\
\text { (Enterprise } \\
\text { Number) }\end{array}$ & $\%$ & $\begin{array}{c}\text { İşletme } \\
\text { Sayısı } \\
\text { (Enterprise } \\
\text { Number) }\end{array}$ & $\%$ & \begin{tabular}{|c|} 
İsletme \\
Sayısı \\
(Enterprise \\
Number)
\end{tabular} & $\%$ & $\begin{array}{c}\text { İşletme } \\
\text { Sayısı } \\
\text { (Enterprise } \\
\text { Number) }\end{array}$ & $\%$ \\
\hline $\begin{array}{l}\text { İsletme içi } \\
(\text { On-premises })\end{array}$ & 5 & 50 & 3 & 75 & 5 & 38.5 & 2 & 25 & 15 & 42.9 \\
\hline $\begin{array}{l}\text { Köy yolu } \\
\text { (Village road) }\end{array}$ & 3 & 30 & 0 & 0 & 0 & 0 & 1 & 12.5 & 4 & 11.4 \\
\hline $\begin{array}{l}\text { Tarla yolu } \\
\text { (Field road })\end{array}$ & 0 & 0 & 1 & 25 & 3 & 23.1 & 1 & 12.5 & 5 & 14.3 \\
\hline Tarla (Field) & 2 & 20 & 0 & 0 & 4 & 30.8 & 4 & 50 & 10 & 28.6 \\
\hline \begin{tabular}{|l} 
Şehir yolu \\
(City road)
\end{tabular} & 0 & 0 & 0 & 0 & 1 & 7.7 & 0 & 0 & 1 & 2.9 \\
\hline Toplam (Total) & 10 & 100 & 4 & 100 & 13 & 100 & 8 & 100 & 35 & 100 \\
\hline
\end{tabular}

Tarım işletmelerinde oluşan iş kazaları gün içinde sabah \%11.4, öğle \%34.3, öğleden sonra \%25.7, akşam $\% 22.9$ ve gece $\% 5.7$ olarak gerçekleşmiştir (Çizelge 5). Tarım işletmelerinde meydana gelen kazaların oluş şekline bakıldığında; devrilme, takla atma, şarampole uçmanın \%42.9, sıkışma-ezilmenin \%31.4, vücudu bir parçaya kaptırmanın \%14.3, vücuda herhangi bir parçanın çarpmasının \%5.7, traktörden düşmenin \%2.9 ve traktörün çarpması/başka araçla çarpışmanın $\% 2.9$ oranında olduğu belirlenmiştir (Çizelge 6).

Cizelge 5. Tarım işletmelerinde iş kazalarının gün içinde oluştuğu zamanlar

Table 5. Times of occupational accidents in agricultural enterprises during the day

\begin{tabular}{|c|c|c|c|c|c|c|c|c|c|c|}
\hline \multirow{3}{*}{$\begin{array}{l}\text { Kazanın oluş } \\
\text { zamanı } \\
(\text { Time of Accident })\end{array}$} & \multicolumn{8}{|c|}{ İler (Provinces) } & \multirow{2}{*}{\multicolumn{2}{|c|}{$\begin{array}{l}\text { Doğu Akdeniz } \\
\text { Bölgesi (Eastern } \\
\text { Mediterranean } \\
\text { Region) }\end{array}$}} \\
\hline & \multicolumn{2}{|l|}{ Adana } & \multicolumn{2}{|c|}{ Hatay } & \multicolumn{2}{|c|}{ Kahramanmaraş } & \multicolumn{2}{|c|}{ Osmaniye } & & \\
\hline & $\begin{array}{c}\text { İşletme } \\
\text { Sayısı } \\
\text { (Enterprise } \\
\text { Number) }\end{array}$ & $\%$ & $\begin{array}{c}\text { İşletme } \\
\text { Sayısı } \\
\text { (Enterprise } \\
\text { Number) }\end{array}$ & $\%$ & $\begin{array}{c}\text { İşletme } \\
\text { Sayısı } \\
\text { (Enterprise } \\
\text { Number) }\end{array}$ & $\%$ & $\begin{array}{c}\text { İşletme } \\
\text { Sayısı } \\
\text { (Enterprise } \\
\text { Number) }\end{array}$ & $\%$ & $\begin{array}{c}\text { İşletme } \\
\text { Sayısı } \\
\text { (Enterprise } \\
\text { Number) }\end{array}$ & $\%$ \\
\hline Sabah (Morning) & 1 & 10 & 0 & 0 & 3 & 23.1 & 0 & 0 & 4 & 11.4 \\
\hline Öğle (Noon) & 2 & 20 & 2 & 50 & 8 & 61.5 & 0 & 0 & 12 & 34.3 \\
\hline $\begin{array}{l}\begin{array}{l}\text { Öğleden sonra } \\
\text { (Afternoon) }\end{array} \\
\end{array}$ & 2 & 20 & 1 & 25 & 1 & 7.7 & 5 & 62.5 & 9 & 25.7 \\
\hline Akşam (Evening) & 5 & 50 & 1 & 25 & 1 & 7.7 & 1 & 12.5 & 8 & 22.9 \\
\hline Gece (Night) & 0 & 0 & 0 & 0 & 0 & 0 & 2 & 25 & 2 & 5.7 \\
\hline Toplam (Total) & 10 & 100 & 4 & 100 & 13 & 100 & 8 & 100 & 35 & 100 \\
\hline
\end{tabular}

Baydaş ve Altuntaş (2017), Tokat, Ankara, Erzurum ve Karaman illerinde meydana gelen kazalara ait bulgulara göre; kazaların iller bazında sırasıyla $\% 26.32 ; \% 44$, \%31 ve \%8.19 oranlarinda tarlada, $\% 37.19 ; \% 47, \% 60$ ve $\% 54.09$ oranlariyla köy ve tarla yolunda meydana geldiği, tarımsal iş kazalarında operatörün traktörü kullanımı sonucu devrilme/takla atma olayı iller bazında sirasıyla; \%49; \%68, \%47 ve $\% 60.4$ oranlarında olduğunu bildirmişlerdir.

Gölbaşı (2002), Türkiye ölçeğinde yapmış olduğu kapsamlı bir çalışmada, traktör kazalarının \%44'nün köy yolunda, \%59'nun devrilme, takla atma ya da şarampole uçma şeklinde gerçekleştiğini tespit etmiştir. Bu çalışmada elde edilen verilere göre $\% 42.9$ oranında kaza olduğu ve köy yolunda \%11.4 oranında kaldığı, bölgede daha çok işletme içerisinde kaza gerçekleştiği ve köy yolunda kaza gerçekleşme oranının düşük ölçüde olduğu görülmektedir. Traktör kazalarının devrilme, takla atma, şarampole uçma \%42.9 ile yüksek oranda olduğu ve geçen süreye rağmen fazla bir değişiklik olmadığını göstermektedir.

Tarım makinalarından kaynaklı oluşan iş kazalarının dağ́lımı Çizelge 7'de verilmiştir.

Tarım makinalarından kaynaklı oluşan iş kazaları değerlendirildiğinde; işletmelerin \%42.9'u traktör, $\% 17.1$ 'i pulluk, \%17.1'i ekim makinası, \%5.7'si gübre makinası, \%5.7'si ilaçlama makinası, \%5.7'si santrifüjlü sulama pompası, \%2.9'u biçerdöver ve $\% 2.9$ 'u silaj makinası ile kaza yaptıklarını bildirmişlerdir (Çizelge 7). 
Hard ve ark. (2002), yapmış oldukları bir çalışmada tarımda yaşanan kazaların \%75'nin traktörden kaynaklandığını ve traktör kazalarının tarımdaki ölümcül kazaların 1/3’ünü oluşturduğunu belirlemiştir. $\mathrm{Bu}$ çalışmada bölge genelinde kazanın meydana geldiği tarım alet makineleri içerisinde traktör kazalarında az bir oranda düşüş gerçekleşmiş̧ olsa da, traktör kaza risklerinin yüksek oranda devam ettiği görülmüsstür.

Çizelge 6. Tarım işletmelerinde traktör ve tarım makineleri ile yapılan iş kazalarının oluş şekli

Table 6. Form of occupational accidents with tractors and agricultural machines in agricultural enterprises

\begin{tabular}{|c|c|c|c|c|c|c|c|c|c|c|}
\hline \multirow{3}{*}{$\begin{array}{l}\text { Kaza oluş şekli } \\
\text { (Type of accident) }\end{array}$} & \multicolumn{8}{|c|}{ İller (Provinces) } & \multirow{2}{*}{\multicolumn{2}{|c|}{$\begin{array}{c}\text { Doğu Akdeniz } \\
\text { Bölgesi (Eastern } \\
\text { Mediterranean } \\
\text { Region) }\end{array}$}} \\
\hline & \multicolumn{2}{|l|}{ Adana } & \multicolumn{2}{|l|}{ Hatay } & \multicolumn{2}{|c|}{ Kahramanmaraş } & \multicolumn{2}{|c|}{ Osmaniye } & & \\
\hline & $\begin{array}{c}\text { İşletme } \\
\text { Sayısı } \\
\text { (Enterprise } \\
\text { Number) }\end{array}$ & $\%$ & $\begin{array}{c}\text { İsletme } \\
\text { Sayısı } \\
\text { (Enterprise } \\
\text { Number) }\end{array}$ & $\%$ & $\begin{array}{c}\text { İşletme } \\
\text { Sayısı } \\
\text { (Enterprise } \\
\text { Number) }\end{array}$ & $\%$ & $\begin{array}{c}\text { İsletme } \\
\text { Sayısı } \\
\text { (Enterprise } \\
\text { Number) }\end{array}$ & $\%$ & $\begin{array}{c}\text { İşletme } \\
\text { Sayısı } \\
\text { (Enterprise } \\
\text { Number) }\end{array}$ & $\%$ \\
\hline $\begin{array}{l}\text { Devrilme, takla atma, } \\
\text { sarampole uçma } \\
\text { (Roll over, somersault, } \\
\text { ditch flying) }\end{array}$ & 2 & 40 & 2 & 25 & 210 & 46.2 & 2. & 50 & 2 & 42.9 \\
\hline $\begin{array}{l}\text { Sikışma-ezilme } \\
\text { (Compression-crush) }\end{array}$ & 3 & 30 & 3 & 75 & 3 & 23.1 & 2 & 25 & 11 & 31.4 \\
\hline $\begin{array}{l}\text { Vücudu bir parçaya } \\
\text { kaptırma } \\
\text { (Don't immerse the body in } \\
\text { a part) }\end{array}$ & 2 & 20 & 0 & 0 & 2 & 15.4 & 1 & 12.5 & 5 & 14.3 \\
\hline $\begin{array}{l}\text { Vücuda herhangi bir } \\
\text { parçanın çarpması } \\
\text { (Hitting any part of the } \\
\text { body) }\end{array}$ & 1 & 10 & 0 & 0 & 1 & 7.7 & 0 & 0 & 2 & 5.7 \\
\hline $\begin{array}{l}\text { Traktörden düşme } \\
\text { (Fall from tractor) }\end{array}$ & 0 & 0 & 0 & 0 & 0 & 0 & 1 & 12.5 & 1 & 2.9 \\
\hline $\begin{array}{l}\text { Traktörün çarpması, } \\
\text { başka araçla çarpışma } \\
\text { (Tractor crash, collision } \\
\text { with another vehicle) }\end{array}$ & 0 & 0 & 0 & 0 & 1 & 7.7 & 0 & 0 & 1 & 2.9 \\
\hline $\begin{array}{l}\text { Toplam } \\
\text { (Total) }\end{array}$ & 10 & 100 & 4 & 100 & 13 & 100 & 8 & 100 & 35 & 100 \\
\hline
\end{tabular}

Çizelge 7. Tarım makinalarından kaynaklı oluşan iş kazalarının dağılımı

Table 7. Distribution of occupational accidents caused by agricultural machinery

\begin{tabular}{|c|c|c|c|c|c|c|c|c|c|c|}
\hline \multirow{3}{*}{$\begin{array}{l}\text { Kazanın meydana } \\
\text { geldiği tarım alet ve } \\
\text { makinasi (Agricultural } \\
\text { tools and machine the } \\
\text { accident occurred) }\end{array}$} & \multicolumn{8}{|c|}{ İller (Provinces) } & \multirow{2}{*}{\multicolumn{2}{|c|}{$\begin{array}{c}\text { Doğu Akdeniz } \\
\text { Bölgesi (Eastern } \\
\text { Mediterranean } \\
\text { Region) } \\
\end{array}$}} \\
\hline & \multicolumn{2}{|l|}{ Adana } & \multicolumn{2}{|l|}{ Hatay } & \multicolumn{2}{|c|}{ Kahramanmaraş } & \multicolumn{2}{|c|}{ Osmaniye } & & \\
\hline & $\begin{array}{c}\text { İşletme } \\
\text { Sayısı } \\
\text { (Enterprise } \\
\text { Number) } \\
\end{array}$ & $\%$ & $\begin{array}{c}\text { İşletme } \\
\text { Sayısı } \\
\text { (Enterprise } \\
\text { Number) } \\
\end{array}$ & $\%$ & $\begin{array}{c}\text { İşletme } \\
\text { Sayısı } \\
\text { (Enterprise } \\
\text { Number) } \\
\end{array}$ & $\%$ & $\begin{array}{c}\text { İşletme } \\
\text { Sayısı } \\
\text { (Enterprise } \\
\text { Number) } \\
\end{array}$ & $\%$ & $\begin{array}{c}\text { İsletme } \\
\text { Sayısı } \\
\text { (Enterprise } \\
\text { Number) } \\
\end{array}$ & $\%$ \\
\hline Traktör (Tractor) & 5 & 50 & 1 & 25 & 5 & 38.5 & 4 & 50 & 15 & 42.9 \\
\hline Pulluk (Plow) & 3 & 30 & 2 & 50 & 1 & 7.7 & 0 & 0 & 6 & 17.1 \\
\hline $\begin{array}{l}\text { Ekim makinası (Sowing } \\
\text { machine) }\end{array}$ & 1 & 10 & 1 & 25 & 1 & 7.7 & 3 & 37.5 & 6 & 17.1 \\
\hline $\begin{array}{l}\text { Gübre makinası } \\
\text { (Fertilizer machine) }\end{array}$ & 0 & 0 & 0 & 0 & 2 & 15.4 & 0 & 0 & 2 & 5.7 \\
\hline $\begin{array}{l}\text { İlaçlama makinası } \\
\text { (Spraying machine) }\end{array}$ & 0 & 0 & 0 & 0 & 1 & 7.7 & 1 & 12.5 & 2 & 5.7 \\
\hline \begin{tabular}{|l|}
$\begin{array}{l}\text { Sulama pompası } \\
\text { (Irrigation pump) }\end{array}$ \\
\end{tabular} & 0 & 0 & 0 & 0 & 2 & 15.5 & 0 & 0 & 2 & 5.7 \\
\hline \begin{tabular}{|l|} 
Biçerdöver \\
(Harvester)
\end{tabular} & 1 & 10 & 0 & 0 & 0 & 0 & 0 & 0 & 1 & 2.9 \\
\hline \begin{tabular}{|l|}
$\begin{array}{l}\text { Silaj makinası } \\
\text { (Silage machine) }\end{array}$ \\
\end{tabular} & 0 & 0 & 0 & 0 & 1 & 7.7 & 0 & 0 & 1 & 2.9 \\
\hline \begin{tabular}{|l|} 
Toplam \\
(TotaI)
\end{tabular} & 10 & 100 & 4 & 100 & 13 & 100 & 8 & 100 & 35 & 100 \\
\hline
\end{tabular}


Kazaya karışan traktör/tarım alet makinasındaki maddi hasar durumu Çizelge 8'de verilmiştir.

Kazalara karışan traktör/tarım alet makinasındaki maddi hasar durumu incelendiğinde, bölgedeki işletmelerde oluşan kazaların \%22.9'unun orta hasarlı, \%17.1'inin az hasarl,, \%2.9'unun çok hasarl,, \%57.1'inin ise hasarsız sonuçlandığı bildirilmiştir
(Çizelge 8).

Tarım işletmelerinde oluşan iş kazalarında etkilenen/karışan kişi sayısı Cizelge 9'da değerlendirilmiştir. Bölgedeki işletmelerin \%87.8'inde bir kişi, \%12.2'sinde ise iki kişi etkilenmiştir (Çizelge 9).

Çizelge 8. Kazaya karışan traktör/tarım alet makinasındaki maddi hasar durumu

Table 8. Material damage to the tractor / agricultural tool machine involved in the accident

\begin{tabular}{|c|c|c|c|c|c|c|c|c|c|c|}
\hline \multirow{3}{*}{$\begin{array}{l}\text { Tarım alet makinası } \\
\text { hasar durumu } \\
\text { (Agricultural } \\
\text { equipment damage } \\
\text { status) }\end{array}$} & \multicolumn{8}{|c|}{ İller (Provinces) } & \multirow{2}{*}{\multicolumn{2}{|c|}{$\begin{array}{c}\text { Doğu Akdeniz } \\
\text { Bölgesi (Eastern } \\
\text { Mediterranean } \\
\text { Region) }\end{array}$}} \\
\hline & \multicolumn{2}{|l|}{ Adana } & \multicolumn{2}{|l|}{ Hatay } & \multicolumn{2}{|c|}{ Kahramanmaraş } & \multicolumn{2}{|c|}{ Osmaniye } & & \\
\hline & $\begin{array}{c}\text { İşletme } \\
\text { Sayısı } \\
\text { (Enterprise } \\
\text { Number) }\end{array}$ & $\%$ & $\begin{array}{c}\text { İşletme } \\
\text { Sayısı } \\
\text { (Enterprise } \\
\text { Number) }\end{array}$ & $\%$ & $\begin{array}{c}\text { İşletme } \\
\text { Sayısı } \\
\text { (Enterprise } \\
\text { Number) }\end{array}$ & $\%$ & $\begin{array}{c}\text { İsletme } \\
\text { Sayısı } \\
\text { (Enterprise } \\
\text { Number) }\end{array}$ & $\%$ & \begin{tabular}{|c|} 
İşletme \\
Sayısı \\
(Enterprise \\
Number $)$
\end{tabular} & $\%$ \\
\hline \begin{tabular}{|l|} 
Çok hasarlı \\
$($ Very damaged)
\end{tabular} & 1 & 9.1 & 0 & 0 & 0 & 0 & 0 & 0 & 1 & 2.9 \\
\hline $\begin{array}{l}\text { Orta hasarlı } \\
\text { (Moderately } \\
\text { damaged) }\end{array}$ & 3 & 27.3 & 0 & 0 & 4 & 28.6 & 1 & 14.3 & 8 & 22.9 \\
\hline $\begin{array}{l}\text { Az hasarlı } \\
\text { (Slightly damaged) }\end{array}$ & 0 & 0 & 0 & 0 & 4 & 28.6 & 2 & 28.6 & 6 & 17.1 \\
\hline $\begin{array}{l}\text { Hasarsiz } \\
(\text { Undamaged })\end{array}$ & 7 & 63.6 & 3 & 100 & 6 & 42.9 & 4 & 57.1 & 20 & 57.1 \\
\hline $\begin{array}{l}\text { Toplam } \\
\text { (Total) }\end{array}$ & 11 & 100 & 3 & 100 & 14 & 100 & 7 & 100 & 35 & 100 \\
\hline
\end{tabular}

Çizelge 9. Tarım işletmelerinde oluşan iş kazalarında etkilenen/karışan kişi sayısı

Table 9. The number of people affected / involved in occupational accidents in agricultural enterprises

\begin{tabular}{|c|c|c|c|c|c|c|c|c|c|c|}
\hline \multirow{3}{*}{$\begin{array}{l}\text { Kazadan etkilenen } \\
\text { kişi sayıs } \\
\text { (Number of people } \\
\text { affected by the } \\
\text { accident) }\end{array}$} & \multicolumn{8}{|c|}{ İller (Provinces) } & \multirow{2}{*}{\multicolumn{2}{|c|}{$\begin{array}{c}\text { Doğu Akdeniz } \\
\text { Bölgesi (Eastern } \\
\text { Mediterranean } \\
\text { Region) }\end{array}$}} \\
\hline & \multicolumn{2}{|l|}{ Adana } & \multicolumn{2}{|l|}{ Hatay } & \multicolumn{2}{|c|}{ Kahramanmaraş } & \multicolumn{2}{|c|}{ Osmaniye } & & \\
\hline & $\begin{array}{c}\text { İşletme } \\
\text { Sayısı } \\
\text { (Enterprise } \\
\text { Number) } \\
\end{array}$ & $\%$ & $\begin{array}{c}\text { İşletme } \\
\text { Sayısı } \\
\text { (Enterprise } \\
\text { Number) }\end{array}$ & $\%$ & $\begin{array}{c}\text { İşletme } \\
\text { Sayısı } \\
\text { (Enterprise } \\
\text { Number) } \\
\end{array}$ & $\%$ & $\begin{array}{c}\text { İşletme } \\
\text { Sayısı } \\
\text { (Enterprise } \\
\text { Number) }\end{array}$ & $\%$ & $\begin{array}{c}\text { İşletme } \\
\text { Sayısı } \\
\text { (Enterprise } \\
\text { Number) }\end{array}$ & $\%$ \\
\hline 1 & 11 & 84.6 & 4 & 100 & 14 & 87.5 & 7 & 87.5 & 36 & 87.8 \\
\hline 2 & 2 & 15.4 & 0 & 0 & 2 & 12.5 & 1 & 12.5 & 5 & 12.2 \\
\hline Toplam (Total) & 13 & 100 & 4 & 100 & 16 & 100 & 8 & 100 & 41 & 100 \\
\hline
\end{tabular}

Kazazedelerin kazadan etkilenme durumu Çizelge 10'da, kazazedelerin kazadan sonra çalışamadığ süreler Çizelge 11'de, kazazede de oluşan zarar yerleri Çizelge 12'de, kazazede de oluşan zararın vücuttaki yeri ise Çizelge 13'te verilmiştir.

Bölgedeki işletmelerde meydana gelen kazalarda kazazedelerin \%15.2'sinin hiç etkilenmediği, \%69.6'sının hafif yaralandığı, \%10.9'unun ağır yaralandığı, \%4.3’ünün kısmen fiziksel engelli olarak kaldığı görülmüştür. Kaza sonucunda tamamen fiziksel engelli ve ölüm olayına rastlanmamıştır (Çizelge 10).

Baydaş ve Altuntaş (2017), Tokat, Ankara ve Erzurum illerindeki kazazedelerin kaza sonucu hafif yaralanma durumunu iller bazında sirasiyla \%37.57; \%28 ve $\% 34$, kazazedelerin ağır yaralanma oranlarının Tokat ve
Erzurum illeri için sırasıyla \%27,16 ve \%28 oranlarında olduğunu bildirmişlerdir. Gölbaşı (2002), Türkiye ölçeğinde yapmış olduğu bir çalışmada kazaya karışan insanların \%77'sinin kazadan bir şekilde (ölüm, ağır ya da hafif yaralanma ve kısmen ya da tamamen fiziksel engelli) etkilendiğini belirlemiştir. $\mathrm{Bu}$ çalışmada kazadan bir şekilde etkilenme durumunda geçen süreye rağmen azalış olmadığı ve yine yüksek bir oranda devam ettiği görülmüştür.

Kazazedelerin kazadan sonra çalışamadığı süreye bakıldığında, (1-14) gün arası \%76.1, (15-30) gün arası $\% 17.4$, (31-90) gün arası \%4.3 ve (90+) günlerde ise \%2.2 olarak görülmüştür (Çizelge 11).

İş kazası sonucu kazazedelerde oluşan zarar şekli incelendiğinde, yaralar ve yüzeysel yaranmalar \%80.4, kemik kırılmaları \%8.7, çıkıklar burkulmalar veya 
incinme \%6.5, uzuv kaybı \%2.2 ve birden fazla yaralanmalar \%2.2 olarak görülmüştür. Beyin sarsıntısı ve iç yaralanmalar ile diğer yaralanmalarda herhangi bir yaralanma sonucuna ulaşılamamıştır (Çizelge 12).

Cizelge 10. Kazazedelerin kazadan etkilenme durumu

Table 10. The conditions of the casualty affected by the accident

\begin{tabular}{|c|c|c|c|c|c|c|c|c|c|c|}
\hline \multirow{3}{*}{$\begin{array}{l}\text { Kazadan etkilenme } \\
\text { durumu } \\
\text { ( Condition of being } \\
\text { affected by the } \\
\text { accident) }\end{array}$} & \multicolumn{8}{|c|}{ İller (Provinces) } & \multirow{2}{*}{\multicolumn{2}{|c|}{$\begin{array}{c}\text { Doğu Akdeniz Bölgesi } \\
\text { (Eastern Mediterranean } \\
\text { Region) }\end{array}$}} \\
\hline & \multicolumn{2}{|l|}{ Adana } & \multicolumn{2}{|l|}{ Hatay } & \multicolumn{2}{|c|}{ Kahramanmaraş } & \multicolumn{2}{|c|}{ Osmaniye } & & \\
\hline & $\begin{array}{c}\text { İşletme } \\
\text { Sayısı } \\
\text { (Enterprise } \\
\text { Number) } \\
\end{array}$ & $\%$ & $\begin{array}{c}\text { İşletme } \\
\text { Sayısı } \\
\text { (Enterprise } \\
\text { Number) } \\
\end{array}$ & $\%$ & \begin{tabular}{|c|} 
İşletme \\
Sayısı \\
(Enterprise \\
Number) \\
\end{tabular} & $\%$ & $\begin{array}{c}\text { İşletme } \\
\text { Sayısı } \\
\text { (Enterprise } \\
\text { Number) } \\
\end{array}$ & $\%$ & $\begin{array}{c}\text { İşletme } \\
\text { Sayısı } \\
\text { (Enterprise } \\
\text { Number) }\end{array}$ & $\%$ \\
\hline $\begin{array}{l}\text { Hiç etkilenmedi } \\
\text { (Not impressed at all) }\end{array}$ & 2 & 11.8 & 1 & 25 & 4 & 23.5 & 0 & 0 & 7 & 15.2 \\
\hline $\begin{array}{l}\text { Hafif yaraland } \\
\text { (Slightly injured) }\end{array}$ & 11 & 64.7 & 3 & 75 & 12 & 70.6 & 6 & 75 & 32 & 69.6 \\
\hline $\begin{array}{l}\text { Ağır yaralandı } \\
\text { (Badly injured) }\end{array}$ & 3 & 17.6 & 0 & 0 & 1 & 5.9 & 1 & 12.5 & 5 & 10.9 \\
\hline $\begin{array}{l}\text { Kısmen fiziksel engelli } \\
\text { (Partially physically } \\
\text { disabled) } \\
\end{array}$ & 1 & 5.9 & 0 & 0 & 0 & 0 & 1 & 12.5 & 2 & 4.3 \\
\hline Toplam (Total) & 17 & 100 & 4 & 100 & 17 & 100 & 8 & 100 & 46 & 100 \\
\hline
\end{tabular}

Çizelge 11. Kazazedelerin kazadan sonra çalışamadığı süreler

Table 11. Periods that casualtys are unable to work after the accident

\begin{tabular}{|c|c|c|c|c|c|c|c|c|c|c|}
\hline \multirow{3}{*}{$\begin{array}{l}\text { Çalışlamayan } \\
\text { süre (gün) } \\
\text { (Non-working } \\
\text { time) (Day) }\end{array}$} & \multicolumn{8}{|c|}{ İler (Provinces) } & \multirow{2}{*}{\multicolumn{2}{|c|}{$\begin{array}{c}\text { Doğu Akdeniz Bölgesi } \\
\text { (Eastern } \\
\text { Mediterranean } \\
\text { Region) }\end{array}$}} \\
\hline & \multicolumn{2}{|c|}{ Adana } & \multicolumn{2}{|l|}{ Hatay } & \multicolumn{2}{|c|}{ Kahramanmaraş } & \multicolumn{2}{|c|}{ Osmaniye } & & \\
\hline & $\begin{array}{c}\text { İşletme } \\
\text { Sayısı } \\
\text { (Enterprise } \\
\text { Number) }\end{array}$ & $\%$ & $\begin{array}{c}\text { İsletme } \\
\text { Sayıs } \\
\text { (Enterprise } \\
\text { Number) }\end{array}$ & $\%$ & $\begin{array}{c}\text { İşletme } \\
\text { Sayısı } \\
\text { (Enterprise } \\
\text { Number) }\end{array}$ & $\%$ & $\begin{array}{c}\text { İşletme } \\
\text { Sayısı } \\
\text { (Enterprise } \\
\text { Number) }\end{array}$ & $\%$ & $\begin{array}{c}\text { İsletme } \\
\text { Sayısı } \\
\text { (Enterprise } \\
\text { Number) }\end{array}$ & $\%$ \\
\hline 1-14 & 12 & 70.6 & 3 & 75 & 16 & 94.1 & 4 & 50 & 35 & 76.1 \\
\hline $15-30$ & 3 & 17.6 & 1 & 25 & 1 & 5.9 & 3 & 37.5 & 8 & 17.4 \\
\hline $31-90$ & 1 & 5.9 & 0 & 0 & 0 & 0 & 1 & 12.5 & 2 & 4.3 \\
\hline $90+$ & 1 & 5.9 & 0 & 0 & 0 & 0 & 0 & 0 & 1 & 2.2 \\
\hline Toplam (Total) & 17 & 100 & 4 & 100 & 17 & 100 & 8 & 100 & 46 & 100 \\
\hline
\end{tabular}

Çizelge 12. İş kazası sonucu kazazedelerde oluşan zarar şekli

Table 12. The type of damage to the casualties as a result of the occupation accident

\begin{tabular}{|c|c|c|c|c|c|c|c|c|c|c|}
\hline \multirow[b]{3}{*}{$\begin{array}{l}\text { Oluşan zarar } \\
\text { (Damage caused) }\end{array}$} & \multicolumn{8}{|c|}{ İller (Provinces) } & \multirow{2}{*}{\multicolumn{2}{|c|}{$\begin{array}{c}\text { Doğu Akdeniz Bölgesi } \\
\text { (Eastern } \\
\text { Mediterranean Region) }\end{array}$}} \\
\hline & \multicolumn{2}{|c|}{ Adana } & \multicolumn{2}{|l|}{ Hatay } & \multicolumn{2}{|c|}{ Kahramanmaraş } & \multicolumn{2}{|c|}{ Osmaniye } & & \\
\hline & \begin{tabular}{|c|} 
İşletme \\
Sayısı \\
(Enterprise \\
Number $)$ \\
\end{tabular} & $\%$ & $\begin{array}{c}\text { İsletme } \\
\text { Sayısı } \\
\text { (Enterprise } \\
\text { Number) } \\
\end{array}$ & $\%$ & $\begin{array}{l}\text { İşletme } \\
\text { Sayısı } \\
\text { (Enterprise } \\
\text { Number) }\end{array}$ & $\%$ & \begin{tabular}{|c|} 
İsletme \\
Sayısı \\
(Enterprise \\
Number) \\
\end{tabular} & $\%$ & $\begin{array}{c}\text { İşletme } \\
\text { Sayisı } \\
\text { (Enterprise } \\
\text { Number) }\end{array}$ & $\%$ \\
\hline $\begin{array}{l}\text { Yaralar ve yüzeysel } \\
\text { yaralanmalar } \\
\text { ( Wounds and superficial } \\
\text { injuries) }\end{array}$ & 13 & 76.5 & 4 & 100 & 16 & 94.1 & 4 & 50 & 37 & 80.4 \\
\hline $\begin{array}{l}\text { Kemik kırılmaları } \\
\text { (Bone fractures) }\end{array}$ & 3 & 17.6 & 0 & 0 & 0 & 0 & 1 & 12.5 & 4 & 8.7 \\
\hline $\begin{array}{l}\text { Çıkıklar, burkulmalar } \\
\text { veya incinme } \\
\text { (Dislocations, sprains or } \\
\text { injuries) }\end{array}$ & 0 & 0 & 0 & 0 & 0 & 0 & 3 & 37.5 & 3 & 6.5 \\
\hline Uzuv kaybı (Amputation) & 0 & 0 & 0 & 0 & 1 & 5.9 & 0 & 0 & 1 & 2.2 \\
\hline $\begin{array}{l}\text { Birden fazla yaralanma } \\
\text { (Multiple injuries) }\end{array}$ & 1 & 5.9 & 0 & 0 & 0 & 0 & 0 & 0 & 1 & 2.2 \\
\hline Toplam (Total) & 17 & 100 & 4 & 100 & 17 & 100 & 8 & 100 & 46 & 100 \\
\hline
\end{tabular}


İş kazası sonucu kazazedede oluşan zararın vücuttaki yeri değerlendirildiğinde; bir eli \%15.1, ayaklardan biri \%7.8, her iki ayak \%0.6, bacaklardan biri \%2.4, göğüs bölgesi \%2.4, sirt bölgesi \%1.2 olarak görülmüş. Ancak her iki eli, baş bölgesi, her iki bacağ ve diğer vücut kısımlarında iş kazası sonucu herhangi bir zarar görülmemiştir (Çizelge 13). Aktuna (2017), Trakya bölgesinde yapmış olduğu bir çalışmada iş kazası geçiren kişilerin en çok el, kol ve vücut yaralanmaları ve iş makinaları sebebiyle yaralanma geçirdiklerini belirtmiştir. Bölge işletmecilerinin de kaza sonucunda benzer olarak en fazla bir el ve bir ayak bölgesinde yaralanma geçirdikleri görülmüştür.
Bölgedeki tarım işletmelerinde kazaya karışan traktörlerin yaşı Çizelge 14'te verilmiştir.

Bölgedeki işletmelerde kazaya karışan traktörlerin $\% 38.2$ 'si 0-5 yaş, \%41.2'si 6-10 yaş, \%2.9'u 11-15 yaş, $\% 8.8$ i $16-20$ yaş ve \%8.7'si ise $21+$ yaş grubunda yer almaktadır (Çizelge 14). Doğan (1992), Çukurova Bölgesinde is kazasina neden olan traktörlerin çoğunun 10 yaşından büyük olduğunu tespit etmiştir. Bölge işletmelerinde iş kazasına karışan traktörlerin yaş ortalamasının 0-10 arasında değiştiği görülmüş, 10+ üzerindeki traktörlerin kazaya karışma oranında düşme yaşandığı gözlemlenmiştir.

Çizelge 13. İş kazası sonucu kazazadede oluşan zararın vücuttaki yeri

Table 13. The place of the damage caused by the occupation accident in the body

\begin{tabular}{|c|c|c|c|c|c|c|c|c|c|c|c|}
\hline \multirow{3}{*}{\multicolumn{2}{|c|}{$\begin{array}{l}\text { İş kazası sonucu vücutta } \\
\text { oluşan zarar } \\
\text { (Damage to the body as a } \\
\text { result of occupational } \\
\text { accident) }\end{array}$}} & \multicolumn{8}{|c|}{ İller (Provinces) } & \multirow{2}{*}{\multicolumn{2}{|c|}{$\begin{array}{l}\text { Doğu Akdeniz } \\
\text { Bölgesi (Eastern } \\
\text { Mediterranean } \\
\text { Region) }\end{array}$}} \\
\hline & & \multicolumn{2}{|l|}{ Adana } & \multicolumn{2}{|l|}{ Hatay } & \multicolumn{2}{|c|}{ Kahramanmaraş } & \multicolumn{2}{|c|}{ Osmaniye } & & \\
\hline & & $\begin{array}{c}\text { İşletme } \\
\text { Sayısı } \\
\text { Enterprise }\end{array}$ & $\%$ & $\begin{array}{c}\text { İşletme } \\
\text { Sayısı } \\
\text { Enterprise }\end{array}$ & $\%$ & $\begin{array}{c}\text { İşletme } \\
\text { Sayısı } \\
\text { Enterprise }\end{array}$ & $\%$ & $\begin{array}{c}\text { İşletme } \\
\text { Sayısı } \\
\text { (Enterprise }\end{array}$ & $\%$ & $\begin{array}{c}\text { İşletme } \\
\text { Sayısı } \\
\text { Enterprise }\end{array}$ & $\%$ \\
\hline \multirow{2}{*}{$\begin{array}{l}\text { Bir eli } \\
\text { (One hand) }\end{array}$} & $\operatorname{Yok}(N o)$ & 42 & 80.8 & 30 & 93.8 & 40 & 80 & 29 & 90.6 & 141 & 84.9 \\
\hline & $\operatorname{Var}(Y e s)$ & 10 & 19.2 & 2 & 6.2 & 10 & 20 & 3 & 9.4 & 25 & 15.1 \\
\hline $\begin{array}{l}\text { Her iki eli } \\
\text { (Both hands) }\end{array}$ & $\operatorname{Yok}(N o)$ & 52 & 100 & 32 & 100 & 50 & 100 & 32 & 100 & 166 & 100 \\
\hline \multirow{2}{*}{$\begin{array}{l}\text { Ayaklardan biri } \\
(\text { One of the feet })\end{array}$} & Yok $(N o)$ & 47 & 90.4 & 32 & 100 & 45 & 90 & 29 & 90.6 & 153 & 92.2 \\
\hline & $\operatorname{Var}(Y e s)$ & 5 & 9.6 & 0 & 0 & 5 & 10 & 3 & 9.4 & 13 & 7.8 \\
\hline \multirow{2}{*}{$\begin{array}{l}\text { Her iki ayak } \\
\text { (Both feet) }\end{array}$} & $\operatorname{Yok}(N o)$ & 52 & 100 & 32 & 100 & 50 & 100 & 31 & 96.9 & 165 & 99.4 \\
\hline & $\operatorname{Var}(Y e s)$ & 0 & 0 & 0 & 0 & 0 & 0 & 1 & 3.1 & 1 & 0.6 \\
\hline $\begin{array}{l}\text { Baş bölgesi } \\
\text { (Head area) }\end{array}$ & $\operatorname{Yok}(N o)$ & 52 & 100 & 32 & 100 & 50 & 100 & 32 & 100 & 166 & 100 \\
\hline \multirow{2}{*}{$\begin{array}{l}\text { Bacaklardan biri } \\
(\text { One of the legs })\end{array}$} & Yok $(N o)$ & 48 & 92.3 & 32 & 100 & 50 & 100 & 32 & 100 & 162 & 97.6 \\
\hline & $\operatorname{Var}(Y e s)$ & 4 & 7.7 & 0 & 0 & 0 & 0 & 0 & 0 & 4 & 2.4 \\
\hline $\begin{array}{l}\text { Her iki bacağ } 1 \\
(\text { Both leggs) }\end{array}$ & Yok $(\mathrm{No})$ & 52 & 100 & 32 & 100 & 50 & 100 & 32 & 100 & 166 & 100 \\
\hline \multirow{2}{*}{$\begin{array}{l}\text { Göğüs bölgesi } \\
\text { (Chest area) }\end{array}$} & $\operatorname{Yok}(N o)$ & 49 & 94.2 & 32 & 100 & 49 & 98 & 32 & 100 & 162 & 97.6 \\
\hline & $\operatorname{Var}(Y e s)$ & 3 & 5.8 & 0 & 0 & 1 & 2 & 0 & 0 & 4 & 2.4 \\
\hline \multirow{2}{*}{$\begin{array}{l}\text { Sirt bölgesi } \\
\text { (Back area) }\end{array}$} & $\operatorname{Yok}(\mathrm{No})$ & 52 & 100 & 32 & 100 & 48 & 96 & 32 & 100 & 164 & 98.8 \\
\hline & $\operatorname{Var}(Y e s)$ & 0 & 0 & 0 & 0 & 2 & 4 & 0 & 0 & 2 & 1.2 \\
\hline
\end{tabular}

Çizelge 14. Tarım işletmelerinde kazaya karışan traktörlerin yaşı

Table 14. Age of tractors involved in accidents in agricultural enterprises

\begin{tabular}{|c|c|c|c|c|c|c|c|c|c|c|}
\hline \multirow{3}{*}{$\mid$\begin{tabular}{lrr} 
Kazaya & \multicolumn{2}{r}{ karışan } \\
traktör & yaş & grubu \\
(Yil) & & \\
(Tractor & age & group \\
involved & in & the \\
accident $)$ & $($ Year $)$
\end{tabular}} & \multicolumn{7}{|c|}{ İller (Provinces) } & \multirow{2}{*}{\multicolumn{3}{|c|}{$\begin{array}{c}\text { Doğu Akdeniz Bölgesi } \\
\text { (Eastern Mediterranean } \\
\text { Region) }\end{array}$}} \\
\hline & \multicolumn{2}{|c|}{ Adana } & \multicolumn{2}{|c|}{ Hatay } & \multicolumn{2}{|c|}{ Kahramanmaraş } & \multirow{2}{*}{\begin{tabular}{|c|} 
Osmaniye \\
İşletme \\
Sayısı \\
(Enterprise \\
Number)
\end{tabular}} & & & \\
\hline & \begin{tabular}{|c|} 
İşletme \\
Sayısı \\
Enterprise \\
Number)
\end{tabular} & $\%$ & \begin{tabular}{|c|} 
İşletme \\
Sayısı \\
(Enterprise \\
Number $)$
\end{tabular} & $\%$ & \begin{tabular}{|c|} 
İşletme \\
Sayısı \\
(Enterprise \\
Number)
\end{tabular} & $\%$ & & $\%$ & $\begin{array}{c}\text { İşletme } \\
\text { Sayısı } \\
\text { (Enterprise } \\
\text { Number) }\end{array}$ & $\%$ \\
\hline $0-5$ & 3 & 33.3 & 0 & 0 & 6 & 42.9 & 4 & 50 & 13 & 38.2 \\
\hline 6-10 & 5 & 56.6 & 2 & 66.7 & 5 & 35.7 & 2 & 25 & 14 & 41.2 \\
\hline $11-15$ & 0 & 0 & 0 & 0 & 0 & 0 & 1 & 12.5 & 1 & 2.9 \\
\hline $16-20$ & 1 & 11.1 & 0 & 0 & 1 & 7.1 & 1 & 12.5 & 3 & 8.8 \\
\hline $21+$ & 0 & 0 & 1 & 33.3 & 2 & 14.2 & 0 & 0 & 3 & 8.7 \\
\hline Toplam (Total) & 9 & 100 & 3 & 100 & 14 & 100 & 8 & 100 & 46 & 100 \\
\hline
\end{tabular}


Tarım işletmelerinde traktörlerle insan taşınmasına ilişsin bilgiler Çizelge 15 'te verilmiştir.

Bölgedeki işletmelerin \%27.7'sinde traktör üzerinde insan taşınmadığı, \%43.4'ünde çamurluk üzerinde, \%21.7'si basamak üzerinde, \%3’ü askı kolları üzerinde ve \%4.2'sinde ise diğer kısımlarda insan taşındığ belirlenmiştir (Çizelge 15).

İşletmecilerin sürücü belgesi durumu Çizelge 16'da, kullanılan traktörlerin koruyucu çatı veya kabin durumu Çizelge 17'de, kontak anahtarının traktör üzerinde birakılma durumu Çizelge 18'de ve işletmecilerin traktör ve makina kullanım-bakım kataloglarını okuma durumu ise Çizelge 19'da verilmiştir.

Bölgedeki traktör sürücülerinin \%99.4'ünde sürücü belgesinin var olduğu, \%0.6'sında ise sürücü belgesinin bulunmadığı görülmüştür. Sürücü belgesi olanların $\% 60.2$ 'sinin B sinıf, \%33.7'sinin E ve \%0.6'sinin ise D sınıfı belgeye sahip bulunduğu saptanmıştır (Çizelge 16). Bölgedeki işletmelerde kullanılan tarım traktörlerinin \%74.7'sinde koruyucu çatı veya kabin bulunduğu, \%25.3'ünde ise bulunmadığ görülmektedir (Çizelge 17).

Baydaş ve Altuntaş (2017), Tokat ve Erzurum illeri genelindeki kazalar sırasında; traktörü kullanan çiftçilerin sürücü belgesi sınıfları iller bazında sırasıyla; B sınıfına sahip sürücü belgesine sahip olanların \%47.85 ve \%15 oranlarında olduğunu, F sınıfına sahip sürücü belgesine sahip olanların $\% 24,76$ ve $\% 33$ oranlarinda olduğunu, herhangi bir sürücü belgesi olmayanlarm oranlarının ise, $\% 22.80$ ve $\% 48$

Çizelge 15. Tarım işletmelerinde traktörlerle insan taşınmasına ilişkin bilgiler

Table 15. Information on transporting people by tractors in agricultural enterprises

\begin{tabular}{|c|c|c|c|c|c|c|c|c|c|c|}
\hline \multirow{3}{*}{$\begin{array}{l}\text { Traktör üzerinde insan } \\
\text { taşınması } \\
\text { (Transporting people on } \\
\text { a tractor) }\end{array}$} & \multicolumn{8}{|c|}{ İler (Provinces) } & \multirow{2}{*}{\multicolumn{2}{|c|}{$\begin{array}{c}\text { Doğu Akdeniz } \\
\text { Bölgesi (Eastern } \\
\text { Mediterranean } \\
\text { Region) }\end{array}$}} \\
\hline & \multicolumn{2}{|l|}{ Adana } & \multicolumn{2}{|l|}{ Hatay } & \multicolumn{2}{|c|}{ Kahramanmaraş } & \multicolumn{2}{|c|}{ Osmaniye } & & \\
\hline & $\begin{array}{c}\text { İşletme } \\
\text { Sayısı } \\
\text { (Enterprise } \\
\text { Number) } \\
\end{array}$ & $\%$ & $\begin{array}{c}\text { İşletme } \\
\text { Sayısı } \\
\text { (Enterprise } \\
\text { Number) } \\
\end{array}$ & $\%$ & $\begin{array}{c}\text { İşletme } \\
\text { Sayısı } \\
\text { (Enterprise } \\
\text { Number) } \\
\end{array}$ & $\%$ & $\begin{array}{c}\text { İşletme } \\
\text { Sayısı } \\
\text { (Enterprise } \\
\text { Number) } \\
\end{array}$ & $\%$ & $\begin{array}{c}\text { İşletme } \\
\text { Sayısı } \\
\text { (Enterprise } \\
\text { Number) } \\
\end{array}$ & $\%$ \\
\hline $\begin{array}{l}\text { Taşımıyorum } \\
\text { (I do not carry) }\end{array}$ & 15 & 28.8 & 3 & 9.4 & 10 & 20 & 18 & 56.3 & 46 & 27.7 \\
\hline $\begin{array}{l}\text { Çamurluk üzerinde } \\
\text { (On the fender) }\end{array}$ & 25 & 48.1 & 18 & 56.3 & 25 & 50 & 4 & 12.5 & 72 & 43.4 \\
\hline $\begin{array}{l}\text { Basamakta } \\
\text { (On the rung) }\end{array}$ & 7 & 13.5 & 11 & 34.4 & 11 & 22 & 7 & 21.9 & 36 & 21.7 \\
\hline $\begin{array}{l}\text { Askı kolları üzerinde } \\
\text { (On the sling arms) } \\
\end{array}$ & 5 & 9.6 & 0 & 0 & 0 & 0 & 0 & 0 & 5 & 3 \\
\hline Diğer (Other) & 0 & 0 & 0 & 0 & 4 & 8 & 3 & 9.4 & 7 & 4.2 \\
\hline Toplam (Total) & 52 & 100 & 32 & 100 & 17 & 100 & 8 & 100 & 46 & 100 \\
\hline
\end{tabular}

Çizelge 16. Traktör sürücülerinin belge bilgileri

Table 16. Documentation information for tractor drivers

\begin{tabular}{|c|c|c|c|c|c|c|c|c|c|c|c|}
\hline \multirow{3}{*}{\multicolumn{2}{|c|}{$\begin{array}{l}\text { Sürücü Belgesi Durumu } \\
\text { (Driver's License Status) }\end{array}$}} & \multicolumn{8}{|c|}{ İller (Provinces) } & \multirow{2}{*}{\multicolumn{2}{|c|}{$\begin{array}{c}\text { Doğu Akdeniz } \\
\text { Bölgesi (Eastern } \\
\text { Mediterranean } \\
\text { Region) }\end{array}$}} \\
\hline & & \multicolumn{2}{|l|}{ Adana } & \multicolumn{2}{|l|}{ Hatay } & \multicolumn{2}{|c|}{ Kahramanmaraş } & \multicolumn{2}{|c|}{ Osmaniye } & & \\
\hline & & $\begin{array}{c}\text { İşletme } \\
\text { Sayısı }\end{array}$ & $\%$ & $\begin{array}{c}\text { İşletme } \\
\text { Sayısı }\end{array}$ & $\%$ & $\begin{array}{c}\text { İşletme } \\
\text { Sayısı }\end{array}$ & $\%$ & $\begin{array}{c}\text { İşletme } \\
\text { Sayısı }\end{array}$ & $\%$ & $\begin{array}{c}\text { İşletme } \\
\text { Sayısı }\end{array}$ & $\%$ \\
\hline \multirow{2}{*}{$\begin{array}{l}\text { Sürücü } \\
\text { Belgesi } \\
\text { (Driver's } \\
\text { license) }\end{array}$} & Yok $(N o)$ & 1 & 1.9 & 0 & 0 & 0 & 0 & 0 & 0 & 1 & 0.6 \\
\hline & $\operatorname{Var}(Y e s)$ & 51 & 98.1 & 32 & 100 & 50 & 100 & 32 & 100 & 165 & 99.4 \\
\hline \multirow{2}{*}{$\begin{array}{l}\text { B sinifi } \\
(\text { Class B) }\end{array}$} & Yok $(\mathrm{No})$ & 19 & 36.5 & 16 & 50 & 24 & 48 & 7 & 21.9 & 66 & 39.8 \\
\hline & $\operatorname{Var}(Y e s)$ & 33 & 63.5 & 16 & 50 & 26 & 52 & 25 & 78.1 & 100 & 60.2 \\
\hline \multirow{2}{*}{$\begin{array}{l}\text { E sinıfi } \\
(\text { Class E })\end{array}$} & Yok $(\mathrm{No})$ & 34 & 65.4 & 18 & 56.2 & 30 & 60 & 28 & 87.5 & 110 & 66.3 \\
\hline & $\operatorname{Var}(Y e s)$ & 18 & 34.6 & 14 & 43.8 & 20 & 40 & 4 & 12.5 & 56 & 33.7 \\
\hline \multirow{2}{*}{$\begin{array}{l}\text { D sinıfı } \\
(\text { Class D) }\end{array}$} & Yok $(N o)$ & 52 & 100 & 32 & 100 & 49 & 98 & 32 & 100 & 165 & 99.4 \\
\hline & $\operatorname{Var}(Y e s)$ & 0 & 0 & 0 & 0 & 1 & 2 & 0 & 0 & 1 & 0.6 \\
\hline
\end{tabular}


Çizelge 17. Tarım işletmelerinde kullanılan traktörlerin koruyucu çatı veya kabin durumu

Table 17. Protective roof or cabin condition of tractors used in agricultural enterprises

\begin{tabular}{|c|c|c|c|c|c|c|c|c|c|c|}
\hline \multirow{3}{*}{$\begin{array}{l}\text { Koruyucu çatı veya } \\
\text { kabin } \\
\text { (Protective roof or } \\
\text { cabin) }\end{array}$} & \multicolumn{8}{|c|}{ İller (Provinces) } & \multirow{2}{*}{\multicolumn{2}{|c|}{$\begin{array}{c}\text { Doğu Akdeniz } \\
\text { Bölgesi (Eastern } \\
\text { Mediterranean } \\
\text { Region) }\end{array}$}} \\
\hline & \multicolumn{2}{|c|}{ Adana } & \multicolumn{2}{|c|}{ Hatay } & \multicolumn{2}{|c|}{ Kahramanmaraş } & \multicolumn{2}{|c|}{ Osmaniye } & & \\
\hline & \begin{tabular}{|c|} 
İşletme \\
Sayısı \\
(Enterprise \\
Number $)$
\end{tabular} & $\%$ & \begin{tabular}{|c|} 
İşletme \\
Sayısı \\
(Enterprise \\
Number $)$
\end{tabular} & $\%$ & \begin{tabular}{|c|} 
İşletme \\
Sayısı \\
(Enterprise \\
Number $)$
\end{tabular} & $\%$ & \begin{tabular}{|c|} 
İşletme \\
Sayısı \\
(Enterprise \\
Number $)$
\end{tabular} & $\%$ & \begin{tabular}{|c|} 
İşletme \\
Sayısı \\
(Enterprise \\
Number $)$
\end{tabular} & $\%$ \\
\hline $\operatorname{Var}(Y e s)$ & 43 & 82.7 & 18 & 56.3 & 38 & 76 & 25 & 78.1 & 124 & 74.7 \\
\hline Yok $(\mathrm{No})$ & 9 & 17.3 & 14 & 43.7 & 12 & 24 & 7 & 21.9 & 42 & 25.3 \\
\hline Toplam (Tota) & 52 & 100 & 32 & 100 & 50 & 100 & 32 & 100 & 166 & 100 \\
\hline
\end{tabular}

Çizelge 18. Kontak anahtarının traktör üzerinde birakılma durumu

Table 18. The ignition key is left on the tractor

\begin{tabular}{|c|c|c|c|c|c|c|c|c|c|c|}
\hline \multirow{3}{*}{$\begin{array}{l}\text { Kontak anahtarının } \\
\text { traktör üzerinde } \\
\text { burakılma nedeni } \\
\text { (Reason for leaving } \\
\text { the ignition key on } \\
\text { the tractor) }\end{array}$} & \multicolumn{8}{|c|}{ İller (Provinces) } & \multirow{2}{*}{\multicolumn{2}{|c|}{$\begin{array}{c}\text { Doğu Akdeniz } \\
\text { Bölgesi (Eastern } \\
\text { Mediterranean } \\
\text { Region) }\end{array}$}} \\
\hline & \multicolumn{2}{|l|}{ Adana } & \multicolumn{2}{|l|}{ Hatay } & \multicolumn{2}{|c|}{ Kahramanmaraş } & \multicolumn{2}{|c|}{ Osmaniye } & & \\
\hline & $\begin{array}{c}\text { İşletme } \\
\text { Sayısı } \\
\text { (Enterprise } \\
\text { Number) }\end{array}$ & $\%$ & $\begin{array}{c}\text { İşletme } \\
\text { Sayısı } \\
\text { (Enterprise } \\
\text { Number) }\end{array}$ & $\%$ & $\begin{array}{c}\text { İşletme } \\
\text { Sayısı } \\
\text { (Enterprise } \\
\text { Number) }\end{array}$ & $\%$ & $\begin{array}{c}\text { İşletme } \\
\text { Sayısı } \\
\text { (Enterprise } \\
\text { Number) }\end{array}$ & $\%$ & $\begin{array}{c}\text { İşletme } \\
\text { Sayısı } \\
\text { (Enterprise } \\
\text { Number) }\end{array}$ & $\%$ \\
\hline $\begin{array}{l}\text { Birakmiyorum } \\
\text { (I'm not leaving) }\end{array}$ & 21 & 40.4 & 8 & 25 & 16 & 32 & 17 & 53.1 & 62 & 37.3 \\
\hline $\begin{array}{l}\text { Bir şey olmaz } \\
\text { (Nothing happens) }\end{array}$ & 14 & 26.9 & 16 & 50 & 19 & 38 & 10 & 31.3 & 59 & 35.5 \\
\hline Alışkanlık (Habit) & 17 & 32.7 & 8 & 25 & 15 & 30 & 5 & 15.6 & 45 & 27.2 \\
\hline Toplam (Tota) & 52 & 100 & 32 & 100 & 50 & 100 & 32 & 100 & 166 & 100 \\
\hline
\end{tabular}

Çizelge 19. Tarım işletmecilerinin traktör ve makina kullanım-bakım kataloglarını okuma durumu

Table 19. The status of agricultural operators to read tractor and machine use-maintenance catalogs

\begin{tabular}{|c|c|c|c|c|c|c|c|c|c|c|}
\hline \multirow{3}{*}{$\begin{array}{l}\text { Traktör ve makina } \\
\text { kullanım-bakım } \\
\text { kataloglarını okuma } \\
\text { durumu } \\
\text { (Status of reading } \\
\text { tractor and machine } \\
\text { usage-maintenance } \\
\text { catalogs) }\end{array}$} & \multicolumn{8}{|c|}{ İller (Provinces) } & \multirow{2}{*}{\multicolumn{2}{|c|}{$\begin{array}{c}\text { Doğu Akdeniz } \\
\text { Bölgesi (Eastern } \\
\text { Mediterranean } \\
\text { Region) }\end{array}$}} \\
\hline & \multicolumn{2}{|c|}{ Adana } & \multicolumn{2}{|c|}{ Hatay } & \multicolumn{2}{|c|}{ Kahramanmaraş } & \multicolumn{2}{|c|}{ Osmaniye } & & \\
\hline & \begin{tabular}{|l|} 
İşletme \\
Sayısı \\
(Enterprise \\
Number) \\
\end{tabular} & $\%$ & \begin{tabular}{|c|} 
İşletme \\
Sayısı \\
(Enterprise \\
Number)
\end{tabular} & $\%$ & $\begin{array}{c}\text { İşletme } \\
\text { Sayısı } \\
\text { (Enterprise } \\
\text { Number })\end{array}$ & $\%$ & \begin{tabular}{|c|} 
İşletme \\
Sayısı \\
(Enterprise \\
Number $)$
\end{tabular} & $\%$ & \begin{tabular}{|c|} 
İşletme \\
Sayısı \\
(Enterprise \\
Number $)$
\end{tabular} & $\%$ \\
\hline Evet (Yes) & 9 & 17.3 & 0 & 0 & 8 & 16 & 7 & 21.9 & 24 & 14.5 \\
\hline Hayır $(\mathrm{No})$ & 43 & 82.7 & 32 & 100 & 42 & 84 & 25 & 78.1 & 142 & 85.5 \\
\hline Toplam (Total) & 52 & 100 & 32 & 100 & 50 & 100 & 32 & 100 & 166 & 100 \\
\hline
\end{tabular}

olduğunu bildirmişlerdir. Gölbaşı (2002), Türkiye ölçeğinde yapmış olduğu bir çalışmada işletmecilerin \%40'ında herhangi bir sürücü belgesinin olmadığını ve kazaya karışan traktörlerin \%82'sinde kabin ya da koruyucu çatı olmadığını tespit etmiştir. Buna göre yapılan çalışmaya nispeten bölge işletmecilerinin çok yüksek oranda (\%99.4) sürücü belgesine sahip olduğu ve kabin varlığının da aynı ölçüde yüksek oranda (\%74.7) var olduğu görülmüştür.

Bölgedeki işletmelerde kontak anahtarının traktör üzerinde bırakılması durumu değerlendirildiğinde, işletmelerin \%37.3'ü bırakmıyorum, \%35.5’i bir şey olmaz, \%27.1'i alışkanlık olarak bildirmiştir (Çizelge 18).

Bölgedeki tarım işletmecilerinin \%85.5’i traktör ve makina kullanım-bakım kataloglarını okumadıklarını, \%14.5’i ise okuduklarını bildirmişlerdir (Çizelge 19). Veriler değerlendirildiğinde işletmecilerin tamamına yakınının kullanma ve bakım kataloglarını okumadığını ve bu hususun traktör ve makine üzerinde kaza risklerini arttırabileceği düşünülmektedir.

\section{Özellikler Arası İlişkilerin Analizi}

Ele alınan bölgedeki tarım işletmelerinde iş sağlığı ve güvenliği uygulamalarına yönelik elde edilen iki değişken arasında ilişki olup olmadığını belirlemek veya iki değişken arasındaki ilişkinin anlamlı olup olmadığını belirlemek amacıyla Ki-Kare bağımsızlık testi uygulanmıştır. Araştırmada ele alınan işletme ve işletmeci özellikleri ile iş kazası oluşma durumunun karşılaştırılması Çizelge 20'de verilmiştir. 
Çizelge 20. Tarım işletmelerindeki özelllikler ile iş kazası oluşma durumunun karşılaştırılması

Table 20. Comparison of the characteristics of agricultural enterprises and the situation of occupational accidents

\begin{tabular}{|c|c|c|c|c|c|c|c|c|}
\hline & \multicolumn{6}{|c|}{$\begin{array}{c}\text { İ Kazası Oluşma Durumu (Kişi) } \\
\text { (Occurrence of occupational accident) (Person) }\end{array}$} & \multirow[t]{3}{*}{$\mathrm{X}^{2}$} & \multirow[t]{3}{*}{$\mathrm{P}$ değeri } \\
\hline & \multicolumn{2}{|c|}{ Evet $(Y e s)$} & \multicolumn{2}{|c|}{ Hayır $(\mathrm{No})$} & \multicolumn{2}{|c|}{ Toplam (Total) } & & \\
\hline & $\begin{array}{c}\text { Sayı } \\
(\text { Number })\end{array}$ & $\%$ & $\begin{array}{c}\text { Sayı } \\
(\text { Number })\end{array}$ & $\%$ & $\begin{array}{c}\text { Sayı } \\
(\text { Number })\end{array}$ & $\%$ & & \\
\hline $\begin{array}{l}\text { Eğitim durumu } \\
\text { (Educational status) }\end{array}$ & & & & & & & \multirow{6}{*}{8.25} & \multirow{6}{*}{$0.041^{* *}$} \\
\hline $\begin{array}{l}\text { İlkokul } \\
\text { (Primary schooI) }\end{array}$ & 16 & 16.30 & 82 & 83.70 & 98 & 100 & & \\
\hline $\begin{array}{l}\text { Ortaokul } \\
\text { (Middle school) }\end{array}$ & 7 & 18.40 & 31 & 81.60 & 38 & 100 & & \\
\hline Lise (High school) & 7 & 36.80 & 12 & 63.20 & 19 & 100 & & \\
\hline Üniversite(University) & 5 & 45.50 & 6 & 54.50 & 11 & 100 & & \\
\hline Toplam (TotaI) & 35 & 21.1 & 131 & 78.9 & 166 & 100 & & \\
\hline \multicolumn{7}{|l|}{$\begin{array}{l}\text { İsletmeci deneyimi } \\
\text { (Operator experience) }\end{array}$} & & \\
\hline $0-20$ & 16 & 22.90 & 54 & 77.10 & 70 & 100 & \multirow{3}{*}{0.22} & \multirow{3}{*}{0.633} \\
\hline $21+$ & 19 & 19.80 & 77 & 80.20 & 96 & 100 & & \\
\hline Toplam (Total) & 35 & 21.10 & 131 & 78.90 & 166 & 100 & & \\
\hline \multicolumn{7}{|l|}{$\begin{array}{l}\text { Traktör yaşı } \\
\text { (Tractor age) }\end{array}$} & & \\
\hline $0-9$ & 27 & 26.00 & 77 & 74.00 & 104 & 100 & \multirow{3}{*}{3.98} & \multirow{3}{*}{$0.046^{* *}$} \\
\hline $10+$ & 8 & 12.90 & 54 & 87.10 & 62 & 100 & & \\
\hline Toplam (Total) & 35 & 21.10 & 131 & 78.90 & 166 & 100 & & \\
\hline \multicolumn{7}{|l|}{ İl (Province) } & \multirow{6}{*}{2.54} & \multirow{6}{*}{0.467} \\
\hline Adana & 10 & 19.20 & 42 & 80.80 & 52 & 100 & & \\
\hline Hatay & 4 & 12.50 & 28 & 87.50 & 32 & 100 & & \\
\hline Kahramanmaraş & 13 & 26.00 & 37 & 74.00 & 50 & 100 & & \\
\hline Osmaniye & 8 & 25.00 & 24 & 75.00 & 32 & 100 & & \\
\hline Toplam (Total) & 35 & 21.10 & 131 & 78.90 & 166 & 100 & & \\
\hline \multicolumn{7}{|l|}{$\begin{array}{l}\text { Traktör ile insan } \\
\text { taşıma (Transporting } \\
\text { people with a tractor) }\end{array}$} & & \\
\hline $\begin{array}{l}\text { Taşımiyor } \\
\text { (Not carrying) }\end{array}$ & 6 & 13.00 & 40 & 87.00 & 46 & 100 & \multirow[t]{3}{*}{2.47} & \multirow[t]{3}{*}{0.116} \\
\hline Taşıyor (Carrying) & 29 & 24.20 & 91 & 75.80 & 120 & 100 & & \\
\hline Toplam (Total) & 35 & 21.10 & 131 & 78.90 & 166 & 100 & & \\
\hline \multicolumn{7}{|l|}{$\begin{array}{l}\text { Ekipman varlığ } \\
\text { (Equipment } \\
\text { availability) }\end{array}$} & & \\
\hline $\operatorname{Var}(Y e s)$ & 23 & 23.70 & 74 & 76.30 & 97 & 100 & \multirow{3}{*}{0.96} & \multirow{3}{*}{0.325} \\
\hline Yok $(\mathrm{No})$ & 12 & 17.40 & 57 & 82.60 & 69 & 100 & & \\
\hline Toplam (Total) & 35 & 21.10 & 131 & 78.90 & 166 & 100 & & \\
\hline \multicolumn{7}{|l|}{$\begin{array}{l}\text { Yıllık Bakım } \\
\text { (Annual Maintenance) }\end{array}$} & & \\
\hline Evet $(Y e s)$ & 32 & 25.20 & 95 & 74.80 & 127 & 100 & \multirow{3}{*}{5.49} & \multirow{3}{*}{$0.019 * *$} \\
\hline Hayır $(\mathrm{No})$ & 3 & 7.70 & 36 & 92.30 & 39 & 100 & & \\
\hline Toplam (Total) & 35 & 21.10 & 131 & 78.90 & 166 & 100 & & \\
\hline
\end{tabular}

***: 0.01 düzeyinde önemli, **: 0.05 düzeyinde önemli, *: 0.1 düzeyinde önemli.

Karşılaştırmaya esas olan yedi işletme ve işletmeci özelliklerinden üç tanesinin istatistiksel olarak önemli olduğu görülmektedir. İşletmecilerin eğitim düzeyleri ile iş kazası oluşma durumu arasında istatistiksel olarak önemli bir ilişki bulunmaktadır $\left(\mathrm{X}^{2}=8.25\right.$; $\mathrm{P}=0.041)$. İşletmecilerin eğitim düzeyleri arttıkça kaza yapma riskleri azalmaktadır. Traktör yıllık bakım yapılma durumu ile iş kazası oluşma durumu arasında pozitif bir bağıntı bulunmaktadır $\left(\mathrm{X}^{2}=5.49 ; \mathrm{P}=0.019\right)$.
Traktör yaşı ile iş kazası oluşma durumu arasında istatistiksel olarak önemli bir ilişki bulunmaktadır $\left(\mathrm{X}^{2}=3.98 ; \mathrm{P}=0.046\right)$. İşletmelerin ve işletmecilerin ele alınan özelliklerinde traktör yıllık bakım yaptıranların daha fazla iş kazasına maruz kaldığı, bu kategoride bakım yaptıranların \%25.2'sinde kaza meydana gelirken, bakım yaptırmayanlarda ise \%7.7 oranında iş kazasının meydana geldiği görülmektedir. $\mathrm{Bu}$ istatistiksel verilere göre başka bir ifade ile 
sonuçlar traktör yaşı ile ilişkilendirilmektedir, traktör yaşının daha çok 0-9 yıl arasında 104 adet değişken tipte traktöre işletmecilerin sahip olması ve bunların \%26'llk bir kısmının kazaya karışmasından dolayı kaza riskleri ve kaza oluşma durumu günümüz yeni nesil traktörlerde daha fazla yaşandığ görülmüştür. İşletmeci tecrübesi, yaşanılan il, traktör ile insan taşıma durumu, gerekli güvenlik koruma ekipman varlığ $\breve{1}_{1}$ ile iş kazası oluşma durumu arasında istatistiksel olarak bir ilişki görülmemektedir. Buradan yola çıkarsak; bahse konu olan istatistiksel veriler ile iş kazası oluşma durumu açısından bağımsızdır (Çizelge 20).

\section{SONUÇ ve ÖNERİLER}

$\mathrm{Bu}$ araştırmada, tarımda çalışanların İş Güvenliği konusunda farkındalıklarını tespit etmek ve duyarlılıklarını arttırmak amacı ile Doğu Akdeniz Bölgesindeki (Adana, Hatay, Kahramanmaraş, Osmaniye) tarım işletmelerinde mekanizasyon yapısı ve iş kazaları anketle belirlenip değerlendirilmiştir.

Elde edilen sonuçlar ve öneriler aşağıdaki gibi özetlenebilir;

- Bölgedeki işletmecilerin; büyük çoğunluğu erkek (\%98.8), genç ve orta yaş grubunda (\%81.3), yarısından fazlası (\%59) ilkokul eğitimlidir.

- Bölgedeki tarım işletmelerinin \%62.7'sinde çalışan bulunmamakta, \%33.7'sinde 1-3 çalışan bulunmakta, \%3.6'sında ise 4-6 çalışan bulunmaktadır.

- Bölgede sulu arazisi bulunan işletmelerin \%47.6'sı ve kuru arazi bulunan işletmelerin \%78.9'u 0-5 ha araziye sahiptir. İşletmelerin \%76.5'i bitkisel üretim, $\% 1.2$ 'si hayvansal üretim ve $\% 22.3$ ü bitkisel+hayvansal üretim faaliyeti gerçekleştirmektedir.

- Bölgedeki tarım işletmelerinin; \%87.3'ünde bir traktör, \%10.2'sinde iki traktör ve \%1.8'inde üç traktör bulunmaktadır. Traktörlerin yaklaşık \%25’inin ekonomik ömrünü tamamladığı, \%15’inin ise yakın dönemde tamamlayacağı ve diğer mekanizasyon araçlarının ise optimum düzeyin altında olduğu saptanmıştır.

- Bölgedeki tarım işletmelerinin \%21.1'inde iş kazaları gerçekleşmiştir. Kazalara sırası ile tarım makinaları, tarım traktörleri, elektrik çarpması, hayvanlar ve diğer araçlar neden olmuştur.

- İş kazaları; işletme içinde (\%42.9), tarlada (\%28.6), köy yolunda (\%11.4), tarla yolunda (\%14.3) ve şehir yolunda (\%2.9) gerçekleşmiştir.

- Kazalar gün içinde en fazla öğle zamanı (\%34.3) gerçekleşmiş̧ir. Bunu sırası ile öğleden sonra (\%25.7), akşam (\%22.9), sabah (\%11.4) ve gece (\%5.7) izlemiştir.

- Kazalar; şarampole uçma (\%42.9), sıkışma-ezilme (\%31.4), vücudu bir parçaya kaptırma (\%14.3), vücuda herhangi bir parçanın çarpması (\%5.7), traktörden düşme (\%2.9), traktörün çarpması/başka araçla çarpışma (\%2.9) şeklinde gerçekleşmiştir.

- Tarım alet makinalarından kaynaklı iş kazaları en fazla pulluk (\%17.1) ve ekim makinası (\%17.1) ile olmuştur. Diğerleri sırası ile gübre dağıtma makinası (\%5.7), ilaçlama makinası (\%5.7), santrifüjlü sulama pompası (\%5.7) ve silaj makinası (\%2.9)'dır.

- Kazalara karışan traktör/tarım alet makinalarının \%57.1'inde hasar oluşmamıştır. $\mathrm{Bu}$ kazaların $\% 22.9$ 'u orta hasarlı, \%17.1'i az hasarll, \%2.9'u ise çok hasarlı olarak sonuçlanmıştır

- Oluşan iş kazalarında bölgedeki işletmelerin \%87.8'inde bir kişi, \% 12.2'sinde ise iki kişi etkilenmiştir.

- Kazazedelerin \%15.2'sinin oluşan kazalardan hiç etkilenmediği, \%69.6'sının hafif yaralandığı, \%10.9'unun ağır yaralandığı, \%4.3'ünün kısmen fiziksel engelli olarak kaldığı belirlenmiştir.

- Kazazedelerin kazadan sonra çalışamadiğı sürelerin oranları; 1-14 gün arası \%76.1, 15-30 gün arası $\% 17.4,31-90$ gün arası $\% 4.3$ ve $90+$ günlerde ise $\% 2.2$ 'dir.

- Kazazedelerde yaralar ve yüzeysel yaralanmalar \%80.4, kemik kırılmaları \%8.7, çıkıklar burkulmalar veya incinme $\% 6.5$, uzuv kaybi $\% 2.2$ ve birden fazla yaralanmalar \%2.2'dir.

- Kazazedede oluşan zararın vücuttaki yeri; bir eli $\% 15.1$, ayaklardan biri \%7.8, her iki ayak \%0.6, bacaklardan biri $\% 2.4$, göğüs bölgesi $\% 2.4$, sırt bölgesi \%1.2 olarak tespit edilmiştir.

- Bölgedeki işletmelerde kazaya karışan traktörlerin $\% 38.2$ 'si 0-5 yaş, \%41.2'si 6-10 yaş, $\% 2.9$ 'u 11-15 yaş, $\% 8.8$ 'i $16-20$ yaş ve $\% 8.7$ 'si ise $21+$ yaş grubundadır.

- Bölgedeki işletmelerin \%72.3’ü traktör üzerinde insan taşımaktadır (çamurluk üzerinde \%43.4, basamak üzerinde $\% 21.7$, askı kolları üzerinde $\% 3$, diğer \%4.2).

- Bölgedeki traktör sürücülerinin tamamına yakını (\%99.4) sürücü belgesine sahiptir.

- Bölgede kullanılan tarım traktörlerinin \%74.7'sinde koruyucu çatı veya kabin bulunmakta, \%25.3’ünde ise bulunmamaktadır.

- Bölgedeki tarım işletmecilerinin büyük çoğunluğu (\%85.5) traktör ve makina kullanım-bakım kataloglarını okumamaktadır.

- İşletmecilerin eğitim düzeyleri ile iş kazası oluşma durumu arasında istatistiksel olarak önemli bir ilişki bulunmaktadır $\quad(\mathrm{P}<0.05)$. İşletmecilerin eğitim düzeyleri arttıkça kaza yapma risklerinin azaldığı görülmektedir.

- Traktör yıllık bakım yapılma durumu ile iş kazası oluşma durumu arasında pozitif bir bağıntı $(\mathrm{P}<0.05)$, traktör yaşı ile iş kazası oluşma durumu arasında da 
istatistiksel olarak önemli bir ilişki bulunmaktadır $(\mathrm{P}<0.05)$.

Konuya ilişkin öneriler:

- İşletmede oluşan iş kazalarının başında tarım makinaları ve traktör kaynaklı kazalar yer almaktadır. Ayrıca işletmecilerin büyük bir çoğunluğunun makine kataloglarını okumadıkları belirlenmiştir. Söz konusu kataloglarda bakım, kullanım ve güvenlik ile ilgili önemli bilgiler yer almaktadır. $\mathrm{Bu}$ konuda makine üreticileri ve bakanlık birimleri tarafından her yıl işletmecilere cazip eğitimler gerçekleştirilebilir.

- Bölgede traktör ile insan taşınmasının yapılan anket sonucunda yüksek oranda olduğu belirlenmiştir. Bu tip taşımaların güvenli olmadığı, kazalara neden olduğu yapılan araştırmalarla ortaya konulmuştur. Bu konuda işletmecilerin eğitilmesi ve bu kültürün yaygınlaştırılması güvenli bir çalışma ortamı sağlayabilecektir.

- İşletmelere tarım alet ve makinalarının alımlarında, koruyucu ekipmanlı olmaları teşvik edilmelidir. Böylece oluşabilecek kaza riskleri azaltılabilecektir.

- Bölgedeki işletmecilerin tarımda ve iş sağllğ güvenliğinde ekonomik olarak sürdürülebilir hale gelmesi için oluşabilecek riskleri minimize etmek ve ekonomik olarak desteklemek işletmeci üzerinde güvenli tarımın artması için etkili olabilecektir.

\section{TEŞEKKÜR}

Çalışma, birinci yazarın yüksek lisans tezinden türetilmiştir. Yazarlar çalışmaya maddi destek sağlayan Kahramanmaraş Sütçü İmam Üniversitesi Bilimsel Araştırma Projeleri Birimi Koordinatörlügü’ne (BAP: Proje No: 2017/6-4 YLS) teşekkür ederler.

\section{Araştırmacıların Katkı Oranı Beyan Özeti}

Yazarlar makaleye eşit oranda katkı sağlamış olduklarını beyan eder.

\section{Çıkar Çatışması Beyanı}

Makale yazarları aralarında herhangi bir çıkar çatışması olmadığını beyan ederler.

\section{KAYNAKLAR}

Akbolat D, Evren N, Yılmaz Ş 2007. Isparta İl Sınırları İçinde 1995- 2003 Yılları Arasında Meydana Gelen Traktör ve Tarım İş Makineleri Kazalarının Değerlendirilmesi. SDÜ Ziraat Fakültesi Dergisi, 2 (1): 7-14.

Aktuna A 2017. Tarım Sektöründe Çalışanların İ̧̧ Sağllğgl ve Güvenliği Çerçevesinde Bilgi, Tutum ve Alg1 Düzeyleri: Tekirdağ Süleymanpaşa Örneği. Namık Kemal Üniversitesi Sosyal Bilimler Enstitüsü Çalışma İktisadı Anabilim Dalı, Yüksek
Lisans Tezi, 138s.

Alçayır A 2018. Konya İli Çumra İlçesi Tarım İsletmelerinde Meydana Gelen Traktör ve Tarım Makineleri Kaynaklı İş Kazalarının Belirlenmesi. Selçuk Üniversitesi Tarım Makineleri ve Teknolojileri Mühendisliği Anabilim Dalı, Yüksek Lisans Tezi, 59s.

Anonim, 1999. Tekerlekli Tarım ve Orman Traktörleri Tip Onayı Yönetmeliği. Resmi Gazete. Sayı 23576. 7 Ocak 1999.

Aybek A, Hurşitoğlu Ç 2002. Kahramanmaraş Yöresi Tarım İşletmelerinin Mekanizasyon Özellikleri Ve $\mathrm{Bu}$ Özellikler Arası İlişkiler. KSÜ Fen Ve Mühendislik Dergisi, 5 (2): 105-113.

Aybek A, Sabancı A 2001. Tarım Makineleri İle Çalışmada Oluşan İş Kazaları, Kaza Giderleri, Kazaların Önlenmesi ve Önemli Güvenlik Kuralları. Sekizinci Ergonomi Kongresi. Dokuz Eylül Üniversitesi İktisadi ve İdari Bilimler Fakültesi, 25-26 Ekim 2001.

Baş T 2008. Anket. Anket Nasıl Hazırlanır? Nasıl Uygulanır? Nasıl Değerlendirilir? (5. Baskı). Seçkin Yayıncılık, 255s, Ankara.

Baydaş F, Altuntaş E 2017. Türkiye'deki Bazı Yörelere Ait Traktör ve Tarım Makinaları Kullanımından Kaynaklanan İş Kazalarına Ait Sonuçların Değerlendirilmesi. Gaziosmanpaşa Bilimsel Araştırma Dergisi, 6 (1): 33-45.

Bülbül H 2006. Ankara'nın Bazı İlçelerinde Tarım Alet ve Makineleri İle Çalışmada Gerçekleşen İ̧̧ Kazalarının İncelenmesi Üzerine Bir Araştırma. AÜ. Fen Bilimleri Enstitüsü Tarım Makineleri Anabilim Dal, Yüksek Lisans Tezi, 47s.

Doğan H 1992. Çukurova Bölgesinde Tarımsal Mekanizasyon İş Güvenliği Sorunları Üzerine Bir Araştırma. Çukurova Üniversitesi Fen Bilimleri Enstitüsü Tarım Makineleri Anabilim Dalı, Yüksek Lisans Tezi, 54s.

Erbörü N 2014. Ankara İli Polatlı İlçesi Sarıba Köyündeki Mevsimlik Tarım İşçilerinde İş Kazası Sıklığı ve İlişkili Etmenler. Gazi Üniversitesi Sağlık Bilimleri Enstitüsü İş Sağlığı ve Güvenliği Anabilim Dalı, Yüksek Lisans Tezi, 125s.

Gölbaşı M 2002. Tarım Alet-Makine ve Traktörlerin Kullanımından Kaynaklanan İş Kazaları Nedenlerinin ve Tahmini Kaza Maliyetleri İndeksinin Belirlenmesi. Ankara Üniversitesi Fen Bilimleri Enstitüsü Tarım Makineleri Anabilim Dall, Doktora Tezi, 235s.

Hard DL, Myers JR, Gerberich SG 2002. Traumatic Injuries in Agriculture. Journal of Agricultural Safety and Health, 8 (1): 51-65.

Miran B 2015. Temel İstatistik. Ege Üniversitesi Basımevi, İzmir.

Nakip M 2006. Pazarlama Araştırmaları Teknikleri ve (SPSS Destekli) Uygulamalar, Genişletilmiş 2.Basım, Seçkin Yayıncılık, Ankara.

Newbold P 1995. Statistical for Business and 
Economics. Prentice-Hall, New Jersey.

Tekin VN 2009. SPSS Uygulamalı İstatistik Teknikleri (2. Baskı). Seçkin Yayıncılık, 274s, Ankara.

Öz E 2005. Ege Bölgesi'nde meydana gelen traktör kazalarının tarımsal iş güvenliği açısından değerlendirilmesi. Ege Üniversitesi Ziraat Fakültesi Dergisi, 42 (2): 191-202.

Özkan A, Dilay Y 2020. Karaman İlinde Tarımsal Üretimde Traktör ve Tarım Makineleri Kaynaklı Kazaların Değerlendirilmesi. Tarım Makinaları Bilimi Dergisi, 16 (1): 32-39.

Öztürk İ 2008. Tokat İl Sinırları İçerisinde Tarım Makineleri Kazaları ve İş Güvenliği Üzerinde Bir Araştırma. GOÜ Fen Bilimleri Enstitüsü, Tarım Makineleri Anabilim Dalı, Yüksek Lisans Tezi, 132s.

Peker A, Özkan A 1994. 1973-1993 Yılları Arasında Karaman Yöresinde Meydana Gelen Traktör ve Tarım İ Makineleri Kazalarının Değerlendirilmesi. Tarımsal Mekanizasyon 15. Ulusal Kongresi, 20- 22 Eylül, S: 475-484, Antalya.

Perktaş MS 2007. Türkiye'de Traktörlerin Karıştığı Trafik Kazalarının Değerlendirilmesi. Gazi Üniversitesi Fen Bilimleri Enstitüsü Trafik Planlaması ve Uygulaması Anabilim Dalı, Yüksek Lisans Tezi, 90s.

Sağlam C, Çetin N, Kuş ZA 2017. Kayseri İlinde Meydana Gelen Traktör ve Tarım Makinaları Kazalarının Değerlendirilmesi. Gaziosmanpaşa
Bilimsel Araştırma Dergisi, 6 (Özel sayı): 20-34.

Şenel H 2006. Doğu Akdeniz Bölgesinde Yaygın Traktörlerin Teknik Özellikleri ve Kullanıcı Değerlendirmeleri. Kahramanmaraş Sütçü İmam Üniversitesi Fen Bilimleri Enstitüsü Tarım Makinaları Ana Bilim Dalı, Yüksek Lisans Tezi, $49 \mathrm{~s}$.

Ünal HG, Yaman K, Gök A 2008. Analysis of Agricultural Accidents in Turkey. Tarım Bilimleri Dergisi, 14 (1): 38-45.

Yavuz H, Şimşek Z 2012. Tarım Sağlığı ve Güvenliği Alanında Dünyada Yapılan Çalışmalar. İş Sağlığı ve Güvenliği Dergisi, 55: 27-32.

Yıldırım C, Altuntaş E 2015. Tokat İlinde Traktör ve Tarım Makinaları Kullanımından Kaynaklanan İş Kazalarının $\dot{I}_{\widehat{S}}$ Güvenliği Açısından Değerlendirilmesi. Gaziosmanpaşa Üniversitesi Ziraat Fakültesi Dergisi, 32 (1): 77-90.

Yılmaz S 2018. Türkiye'de Tarımsal Mekanizasyon Düzeyi Ve Traktör Parkı Yenilenme Oranlarının Belirlenmesi. Çanakkale Onsekiz Mart Üniversitesi Fen Bilimleri Enstitüsü Tarım Makinaları ve Teknolojileri Mühendisliği Anabilim Dal, Yüksek Lisans Tezi, 146s.

Yücel S 2012. Erzurum İlinde Traktör ve Alet Makine Kullanımı Sırasında Oluşan Kazalar ve Sonuçları Üzerine Bir Araştırma, Atatürk Üniversitesi Fen Bilimleri Enstitüsü Tarım Makineleri Anabilim Dalı, Yüksek Lisans Tezi, 64s. 